\title{
Smoke injection heights from fires in North America: analysis of 5 years of satellite observations
}

\author{
M. Val Martin ${ }^{1}$, J. A. $\operatorname{Logan}^{1}$, R. A. Kahn ${ }^{2}$, F.-Y. Leung ${ }^{3}$, D. L. Nelson ${ }^{4}$, and D. J. Diner ${ }^{5}$ \\ ${ }^{1}$ School of Engineering and Applied Science, Harvard University, Cambridge, MA, USA \\ ${ }^{2}$ NASA Goddard Space Flight Center,Greenbelt, MD, USA \\ ${ }^{3}$ Washington State University, Pullman, WA, USA \\ ${ }^{4}$ Raytheon Intelligence and Information Systems, Pasadena, CA, USA \\ ${ }^{5}$ Jet Propulsion Laboratory, California Institute of Technology, Pasadena, CA, USA
}

Received: 14 August 2009 - Published in Atmos. Chem. Phys. Discuss.: 30 September 2009

Revised: 20 January 2010 - Accepted: 26 January 2010 - Published: 15 February 2010

\begin{abstract}
We analyze an extensive record of aerosol smoke plume heights derived from observations over North America for the fire seasons of 2002 and 2004-2007 made by the Multi-angle Imaging SpectroRadiometer (MISR) instrument on board the NASA Earth Observing System Terra satellite. We characterize the magnitude and variability of smoke plume heights for various biomes, and assess the contribution of local atmospheric and fire conditions to this variability. Plume heights are highly variable, ranging from a few hundred meters up to $5000 \mathrm{~m}$ above the terrain at the Terra overpass time (11:00-14:00 local time). The largest plumes are found over the boreal region (median values of $\sim 850 \mathrm{~m}$ height, $24 \mathrm{~km}$ length and $940 \mathrm{~m}$ thickness), whereas the smallest plumes are found over cropland and grassland fires in the contiguous US (median values of $\sim 530 \mathrm{~m}$ height, $12 \mathrm{~km}$ length and $550-640 \mathrm{~m}$ thickness). The analysis of plume heights in combination with assimilated meteorological observations from the NASA Goddard Earth Observing System indicates that a significant fraction (4-12\%) of plumes from fires are injected above the boundary layer (BL), consistent with earlier results for Alaska and the Yukon Territories during summer 2004. Most of the plumes located above the $\mathrm{BL}(>83 \%)$ are trapped within stable atmospheric layers. We find a correlation between plume height and the MODerate resolution Imaging Spectroradiometer (MODIS) fire radiative power (FRP) thermal anomalies associated with each plume. Smoke plumes located in the free troposphere
\end{abstract}

Correspondence to: M. Val Martin (mvalmart@seas.harvard.edu)
(FT) exhibit larger FRP values (1620-1640 MW) than those remaining within the BL (174-465 MW). Plumes located in the FT without a stable layer reach higher altitudes and are more spread-out vertically than those associated with distinct stable layers $(2490 \mathrm{~m}$ height and $2790 \mathrm{~m}$ thickness versus $1880 \mathrm{~m}$ height and $1800 \mathrm{~m}$ thickness). The MISR plume climatology exhibits a well-defined seasonal cycle of plume heights in boreal and temperate biomes, with greater heights during June-July. MODIS FRP measurements indicate that larger summertime heights are the result of higher fire intensity, likely due to more severe fire weather during these months. This work demonstrates the significant effect of fire intensity and atmospheric structure on the ultimate rise of fire emissions, and underlines the importance of considering such physical processes in modeling smoke dispersion.

\section{Introduction}

Emissions from fires contribute significantly to the composition of the atmosphere at regional to global scales. A wide range of chemically active trace gases (e.g. CO, non-methane hydrocarbons, nitrogen oxides) are released during combustion (e.g. Goode et al., 2000; Andreae and Merlet, 2001), with potentially important consequences for the oxidizing capacity of the atmosphere and tropospheric $\mathrm{O}_{3}$ formation. In addition, fires are important sources of aerosols, which have strong radiative effects (e.g. Forster et al., 2007).

The altitude reached by fires emissions is a complex function of fire energy and local meteorology present at the time of burning. As a result, fires show large variability in the

Published by Copernicus Publications on behalf of the European Geosciences Union. 
vertical distribution of emissions near the source, often referred to as the injection height. For instance, some studies have shown that smoke plumes from individual fires are often completely trapped within the boundary layer (BL) (e.g. Trentmann et al., 2002). In contrast, other studies determined that major fires can produce enough energy to inject emissions above the BL. Aircraft measurements made over Alaska and Canada detected plumes from boreal wildfires between 2 to $7 \mathrm{~km}$ (e.g. Wofsy et al., 1992; Blake et al., 1994; de Gouw et al., 2006).Wildfire plumes can even reach the lower stratosphere $(>10 \mathrm{~km})$ due to strong convection associated with the fires, but such pyro-convective events are not common (e.g. Fromm et al., 2000, 2005; Damoah et al., 2006). Based on three experimental fires and one wildfire, Lavoue et al. (2000) showed that plume height is directly proportional to the energy released along the flame front; the plumes from these fires reached altitudes from $2.2 \mathrm{~km}$ to $13 \mathrm{~km}$. Emitted trace gases and aerosols that escape the BL have longer lifetimes, and are subject to long-range transport, with the potential to affect air quality far downwind from the fire sources. Fire plumes above the BL have been detected over continental (e.g. Wotawa and Trainer, 2000; Duck et al., 2007; Colarco et al., 2004), intercontinental (e.g. Honrath et al., 2004; Val Martin et al., 2006; Real et al., 2007), and even hemispheric (e.g. Damoah et al., 2004; Dirksen et al., 2009) scales.

Recently, space-based observations of aerosols have been used to assess the frequency distribution of smoke injection heights above the BL. Labonne et al. (2007), using data from the Cloud-Aerosol Lidar with Orthogonal Polarization (CALIOP) on board the CALIPSO satellite, found that wildfire smoke tends to remain within the BL, and lofting of emissions above the BL occurs rarely. In contrast, Kahn et al. (2008), using data from the Multi-angle Imaging SpectroRadiometer (MISR) instrument on board the NASA Terra satellite, indicated that about $5-18 \%$ of the plumes reached the free troposphere (FT) over Alaska and the Yukon Territories in 2004; the altitude of the observed plumes ranged from a few hundred meters to $4.5 \mathrm{~km}$ above the terrain. The spatial coverage of MISR's multi-angle imaging is vastly greater than that of the CALIPSO lidar. On the other hand, the CALIPSO lidar has sensitivity to the vertical distribution of dispersed aerosol away from sources, where MISR has none. As a result, CALIOP rarely observes the actual sources observed by MISR, but captures the boundary layer smoke that most fires spread over the surrounding region. Thus, the disparity between the CALIOP and MISR results is mostly due to differences in the spatial sampling and sensitivity of the satellite instruments (Kahn et al., 2008), and highlights the complexities involved when collecting representative fire plume height data over a variety of locations.

Global and regional chemical transport models (CTMs) have been used to study the impact of fire emissions on atmospheric composition and air quality. The use of realistic injection heights for fire emissions is thus fundamental to accurately simulating the transport pathways and chemical evolution of fire plumes. At present, it is unclear how best to represent the vertical distribution of fire emissions in CTMs because of a lack of data with which to test the parameterizations. Often, a constant injection height is assumed. In current CTMs, emissions are either released initially within the BL (e.g. Lamarque et al., 20003; Colarco et al., 2004), released at specified altitudes based on an empirical height-fire intensity relationship (Lavoue et al., 2000), mixed throughout the troposphere (e.g. Pfister et al., 2006), or a pre-selected fraction is released within and above the BL (e.g. Leung et al., 2007; Turquety et al., 2007; Generoso et al., 2007; Hyer et al., 2007). These later studies had to release about $50 \%$ of the emissions above the BL to match downwind observations of $\mathrm{CO}$ or aerosols. Recently, some modeling efforts have been made to embed a sub-grid plumerise model scheme into to CMTs (Freitas et al., 2007; Guan et al., 2008), and to consider injection heights derived from the MISR smoke plume height data of Kahn et al. (2008), for example Chen et al. (2009). However, quantifying and modeling fire emission heights remains a difficult task, because of the scarcity of plume height observations for validation.

In this paper, we present a multi-year record of aerosol smoke plume heights over North America, derived from observations made by the MISR instrument on board the NASA Earth Observing System Terra satellite. These data are analyzed in combination with simultaneous measurements of fire radiative power (FRP) from the MODerate resolution Imaging Spectroradiometer (MODIS), also on board the Terra satellite, and assimilated meteorological observations from the NASA Goddard Earth Observing System (GEOS). The objectives of this analysis are: (a) to characterize typical smoke plume heights from fires over different North American biomes; (b) to assess the effect of local atmospheric conditions and fire intensity on smoke vertical distribution; and (c) to determine the seasonal and inter-annual variation of plume smoke heights.

\section{Methodology}

\subsection{Aerosol smoke plume physical characteristics}

Aerosol smoke plume heights from fires over North America were derived using stereo-height retrievals of wildfire plumes obtained from the MISR instrument for the fire seasons of 2002 and 2004-2007 (15 February 2002 to 15 November 2007). We chose the years of 2002 and 2004-2007 since they were high fire years (in terms of area burned) in Alaska (2004 and 2005), Canada (2002 and 2004), and the contiguous US (2006 and 2007). These years included very low fire years in Alaska (2006 and 2007) and the contiguous US (2004), relatively low fire years in Canada (2005 and 2007), and near average fire years in the contiguous US (2002 and 2005). Fire characteristics associated with the plumes were 
obtained from measurements of fire radiative power from MODIS. The MISR Interactive eXplorer (MINX) analysis software package was used to retrieve the physical parameters and develop the plume height climatology presented in this work. Because MISR, MODIS and MINX have already been described elsewhere (Diner et al., 1998; Kaufman et al., 1998; Nelson et al., 2008a, respectively), only a brief summary of the most relevant aspects is presented below.

\subsubsection{MISR and MODIS overview}

The MISR instrument is aboard the NASA's Earth Observing System Terra satellite (Diner et al., 1998), which flies in a near-polar, descending orbit with a dayside equator crossing of about 10:30 local time. MISR acquires multi-angle radiance imagery from a set of nine push-broom cameras, from $-70^{\circ}$ to $+70^{\circ}$ viewing angles, in-line with the ground track of the satellite. The width of the MISR swath common to all 9 cameras is about $380 \mathrm{~km}$, enabling global coverage every 9 days at the equator and every 4-5 days over the boreal forests near $60^{\circ}$. Atmospheric and surface property data are acquired in four spectral bands in each camera: 446, 558, 672 , and $866 \mathrm{~nm}$. MISR's multiple view angles allow the retrieval of cloud, smoke plume, and other aerosol layer heights above the terrain, as well as motion vectors, using stereoscopic methods, with a typical vertical resolution of $500 \mathrm{~m}$ or better, and a horizontal resolution of $1.1 \mathrm{~km}$, provided the cloud or aerosol contains features that can be identified in the multiple views (e.g. Moroney et al., 2002; Muller et al., 2002; Kahn et al., 2007).

The MODIS sensor has middle- and long-wave infrared bands designed specifically to observe actively burning fires (Kaufman et al., 1998; Giglio et al., 2003). Fire pixels are $1 \mathrm{~km}^{2}$ in size at nadir. In addition, MODIS reports radiant energy flux, based on an interpretation of data from two $4 \mu \mathrm{m}$ channels and one $11 \mu \mathrm{m}$ channel (MODIS bands 21 , 22, and 31) (e.g. Justice et al., 2002; Kaufman et al., 2003). The instantaneous radiant energy flux is derived by matching the MODIS measured fire temperature $\left(T_{4}\right)$ and background $\left(T_{4 b}\right)$ at $4 \mu \mathrm{m}$ with a blackbody curve (i.e. $4.34 \times 10^{-19}\left(T_{4}^{8}-\right.$ $\left.T_{4 b}^{8}\right)$, in MW km ${ }^{-2}$ or MW per pixel; Kaufman et al., 1998); it is used as an indicator of fire intensity.

\subsubsection{Smoke plume stereo-height digitization}

Smoke plume heights were retrieved using the MINX tool (Nelson et al., 2008a). Plume digitization occurs in several steps, as shown in Fig. 1. First, MODIS fire pixels are used to locate areas in the MISR field of view where plumes are likely to be found (Fig. 1a). The MODIS level 2 fire products from Collection 4 and Collection 5 were used to identify the fire locations. The source and the boundaries of each plume, and the plume direction of transport are identified by the MINX user who digitizes the periphery of the plume core with the mouse (Fig. 1b). The transport direction
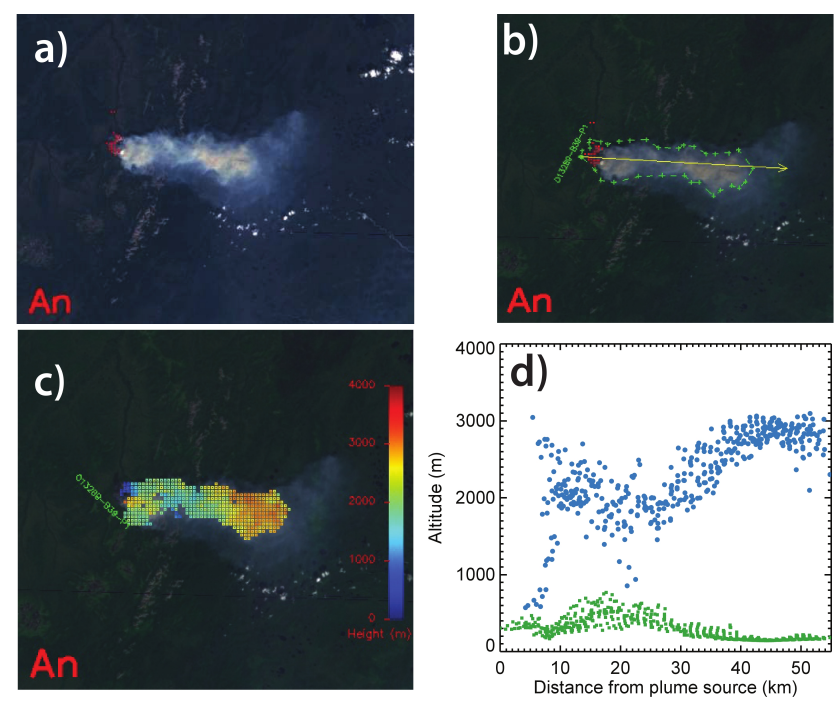

Fig. 1. Example of a MISR plume over central Alaska in 2002: (a) MISR nadir visible image of the smoke with the associated MODIS thermal fire pixels superposed (red dots); (b) MISR plume with the digitized core periphery (green cross symbols). The transport direction of the plume is shown with a yellow arrow; (c) Stereo-heights calculated and superposed on the plume image by the MINX tool; (d) Cross-sectional plot of the wind-corrected stereo-heights as a function of the distance from the fire (blue circles). Terrain heights are shown as green squares.

is used by the MINX algorithm to help compute the wind speed. During the analysis phase, MINX automatically computes smoke heights, wind speeds and albedos. Figure 1c shows the stereo-height points successfully retrieved within the plume core area.

MINX also reads aerosol properties (e.g. Angstrom exponent, single-scattering albedo) from the MISR aerosol standard product, and total fire radiative power (in MW) and brightness temperatures from the MODIS thermal anomaly product. Further details about using MINX and processing the MISR and MODIS data are given by Nelson et al. (2008a). More examples of digitized plumes can be found in Nelson et al. (2008d). The MINX tool is available at http://www.openchannelfoundation.org/projects/MINX.

In addition to the MINX plume heights, which must be digitized plume-by-plume, there is a MISR standard stereo height product, which runs operationally on the entire MISR data stream, but does not classify individual aerosol plumes, clouds, or other features. The standard stereo product provides two types of heights: zero-wind and wind-corrected heights. Zero-wind heights are determined by assuming that disparities in features observed by the different camera views are caused entirely by the satellite displacement or geometric parallax. Wind-corrected heights are determined by considering the additional plume-displacement caused by the wind, the speed and direction of which are determined from automated stereo processing of data from camera triplets. Kahn 


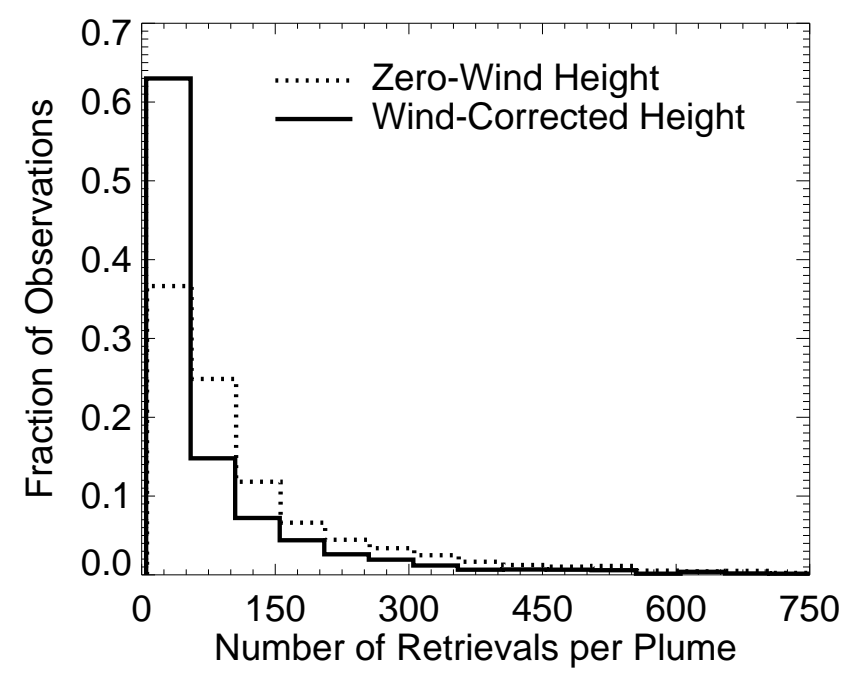

Fig. 2. Histogram of wind-corrected (solid line) and zero-wind (dashed line) stereo-height retrievals per plume. A few data points having more than 750 height retrievals are not shown, to better illustrate the distribution of data values (48 wind-corrected and 99 zerowind plume heights were eliminated).

et al. (2007) emphasize that the wind-corrected product is more accurate, although it provides less spatial coverage.

MINX also provides zero-wind and wind-corrected height values. Figure 2 displays the number of wind-corrected stereo-height pixels per plume obtained from MINX, for the MISR plume climatology used in this study. The median number of stereo-height retrievals per plume is 33 , and about $40 \%$ of the plumes have 50 or more stereo-height retrievals. In Fig. 2, we also show the number of zero-wind stereoheight pixels per plume, for comparison. Note that because MINX involves a human operator, the wind direction is prescribed from the plume morphology, and only the scalar wind speed is derived.

The MINX tool also extracts aerosol heights for smoke clouds, i.e. regions of dispersed smoke that have no clear connection to a particular fire. In this case, the sources of the fire(s) (i.e. MODIS fire pixels) are not available and the transport direction of the smoke cannot be determined. Hence, MINX cannot compute the wind speed, and only zero-wind heights are retrieved. The smoke cloud zero-wind heights include all heights that MINX retrieves successfully, including points very near to or on the ground. To avoid this bias in the data, we removed stereo-heights digitized within $250 \mathrm{~m}$ of the surface (i.e. zero-wind height-terrain height $<250 \mathrm{~m}$ ). This screening procedure excluded about $25 \%$ of the observations. In this paper, however, we report results from the filtered and non-filtered smoke cloud heights. Fire properties associated with the smoke clouds are obviously not available.

Using MINX to digitize smoke plumes and clouds is a relatively simple, if somewhat labor intensive process. However, caution is required in the interpretation of the smoke stereo-height data, as bias and errors are inherent in the digitizing process. For example, some smoke plumes and clouds potentially contain stereo-height retrievals from clouds. Pyro-cumulus clouds intermingled with smoke were deliberately excluded, so there may be a bias against cases of pyroconvection. Stereo-height retrievals from thin aerosols and over bright surfaces may be retrieved with low quality. The wind direction may be determined incorrectly, or the wind direction may be along-track, in which case the wind speed cannot be accurately derived from the MINX algorithm (this limitation does not apply to the MISR operational stereo product).

An important limitation of the MISR plume data is related to the spatial and temporal systemic bias caused by the MISR instrument and the Terra orbit. MISR plume height observations are limited to the Terra satellite overpass time, which is about 10:30 local time at the equator. MISR overpass times, in the region of this study, range from about 11:10 to 13:45 local time, depending on plume location. Thus, a significant diurnal bias is present in the plume heights; the MISR overpass time does not coincide with the late afternoon maximum of fire intensity (Giglio et al., 2006; Ichoku et al., 2008). In addition, the MISR instrument's $380 \mathrm{~km}$ swath covers North America every 4-8 days. This results in an under-sampling of fires, even though multiple plume heights are recorded from the same fire and day. These potential sources of bias, and others, are discussed in detail in Nelson et al. (2008c) and Kahn et al. (2008), and will be considered in the interpretation of the results below.

In this analysis, to minimize the potential effect of inherent errors and bias, we excluded plumes digitized with poor quality (Nelson et al., 2008b). This screening procedure removed plumes characterized by fewer than four height retrievals, those with less than $10 \%$ of the digitized area covered by height retrievals, those with less than a $10^{\circ}$ difference between the plume direction and the satellite along-track direction, and those showing large variability in the stereo-height values (i.e. when the standard deviation of retrieved heights divided by the mean of those values is above 0.45 ). This excluded about $9 \%$ and $5 \%$ of the MISR digitized smoke plumes and clouds, respectively, leaving a total sample size of 3367 smoke plumes and 243 smoke clouds. Our study includes the subset of 664 MISR plumes over Alaska and Yukon Territories in 2004 analyzed by Kahn et al. (2008). Figure 3 displays the locations of the smoke plumes and clouds analyzed in this work.

\subsubsection{Plume height definition}

The plume stereo-height retrievals show different vertical distributions in the atmosphere, likely as a result of different plume-rise dynamics (Kahn et al., 2007; Nelson et al., 2008d). The pixels of some plumes are normally distributed, whereas others are skewed and present one (or more) modes, in which a large number of pixels are distributed 
asymmetrically or in long tails. We used five definitions of plume height in the analysis, to determine if our results depended on the definition of the plume height: (1) the best estimated median height for each plume, i.e. median height after a plane is fitted to all successful height points within the plume, after removing all points more than 1.5 standard deviations from the plane, the primary definition adopted by Kahn et al. (2008); (2) the mode height for each plume, i.e. the $250 \mathrm{~m}$ bin with the largest number of pixels; (3) the average height for each plume, i.e. mean height of all height retrievals within the plume; (4) the individual stereoheight retrievals for the entire dataset i.e. all pixels from all plumes averaged together; and (5) the best estimated maximum height for each plume, i.e. maximum height after a plane is fitted to all successful height points within a plume, after removing all points more than 1.5 standard deviations from the plane. Figure 4a shows an example for a plume that is normally distributed in the vertical, and highlights four definitions of plume heights (i.e. maximum, average, median and mode). The best estimated median and maximum heights for each plume are aimed at minimizing the potential bias from cloud contamination.

Other physical characteristics of the plumes considered in this analysis are the length and the thickness of the plume. The plume length is defined as the distance between the first digitized stereo-height retrieval closest to the fire source and the farthest digitized point (e.g. $52 \mathrm{~km}$ in Fig. 1); The plume thickness is the difference between the best estimated maximum height and the height of the lowest observed stereoheight (e.g. $3500 \mathrm{~m}$ in Fig. 4 a).

\subsection{Atmospheric stability conditions}

We used the results from the meteorological data assimilation scheme from the GEOS model of the NASA Global Modeling and Assimilation Office to determine the atmospheric stability structure at the locations of the plumes. The original GEOS fields had resolutions of $1^{\circ}$ latitude by $1.25^{\circ}$ longitude (GEOS-4) and $0.5^{\circ}$ latitude by $0.67^{\circ}$ longitude (GEOS-5) (Bloom et al., 2005; Rienecker et al., 2008). In this analysis, we used the fields that were archived for running the GEOSChem global model, with degraded resolution of $2^{\circ}$ latitude by $2.5^{\circ}$ longitude. The temporal resolution of the data is $6 \mathrm{~h}$ ( $3 \mathrm{~h}$ for surface variables and mixing depths). We extracted data from GEOS-4 for 2002 and 2004-2006, and GEOS-5 for 2007. GEOS-4 has 55 vertical levels between the surface and $0.01 \mathrm{hPa}$ (including 5 levels up to $2 \mathrm{~km}$ ), whereas GEOS-5 has 72 vertical levels, with 14 levels up to $2 \mathrm{~km}$.

To assess the relationship between the vertical distribution of the smoke stereo-height retrievals and the atmospheric structure, we derived the atmospheric stability profiles at the location and time of the MISR plumes (Kahn et al., 2007). We considered the atmospheric stability as the change in potential temperature with height (Holton, 1992). Because of the coarse vertical resolution of the GEOS data and the un-

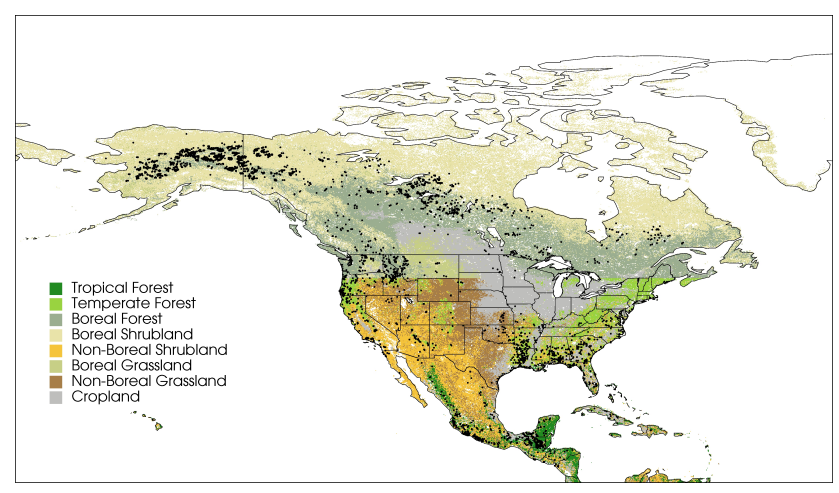

Fig. 3. Locations of the MISR-derived plume heights over North America for 2002, and 2004-2007 are plotted as black dots. Also shown is the spatial distribution of MODIS land cover-based biomes.

equal spacing of the vertical levels of the model, the atmospheric stability values were derived using a 3-point central difference approach centered at the mid-point between the GEOS model levels, that is,

$S_{j}=\frac{\theta_{i+1}-\theta_{i}}{z_{i+1}-z_{i}}$,

where $S_{j}$ is the stability at the mid-point of the model levels $(i$ and $i+1)$, and $\theta$ and $z$ are the potential temperature and altitude respectively at the model levels. The potential temperature was calculated as:

$\theta=T\left(\frac{P_{o}}{P}\right)^{R / C_{p}}$,

in which $T$ and $P$ are the atmospheric temperature and pressure, respectively, at altitude $z, P_{o}$ is the surface pressure, $R$ is the gas constant for dry air, and $C_{p}$ is the specific heat for dry air (Holton, 1992). Altitude levels were estimated from the pressures at each model sigma layer (calculated from the local surface pressure) using the US standard atmosphere. Temperature and pressure were available every $6 \mathrm{~h}$, and these were interpolated to the time of the MISR overpass.

The height of the stable layer was defined as the height of the first maximum in the atmospheric stability profile, with the requirement that the stability was at least one unit (i.e. $1 \mathrm{~K} \mathrm{~km}^{-1}$ ) larger than that at the layers above and below for GEOS-4 and three layers above and below for GEOS5 , or one and a half unit (i.e. $1.5 \mathrm{~K} \mathrm{~km}^{-1}$ ) larger than that at the two layers above and below for GEOS-4 and six layers above and below for GEOS-5. We used more layers for GEOS- 5 because of its higher vertical resolution. The stable layer height is given above sea level. Figure $4 \mathrm{~b}$ displays the atmospheric stability profile at the location and time of the plume example in Fig. 4a. The height of a distinct stable layer is noted in Fig. 4b. We considered the depth of the stable layer to be the difference between the height of the top of the stable layer and the height of the bottom of the stable layer (e.g. $2000 \mathrm{~m}$ in Fig. 4b, with the top height of about 

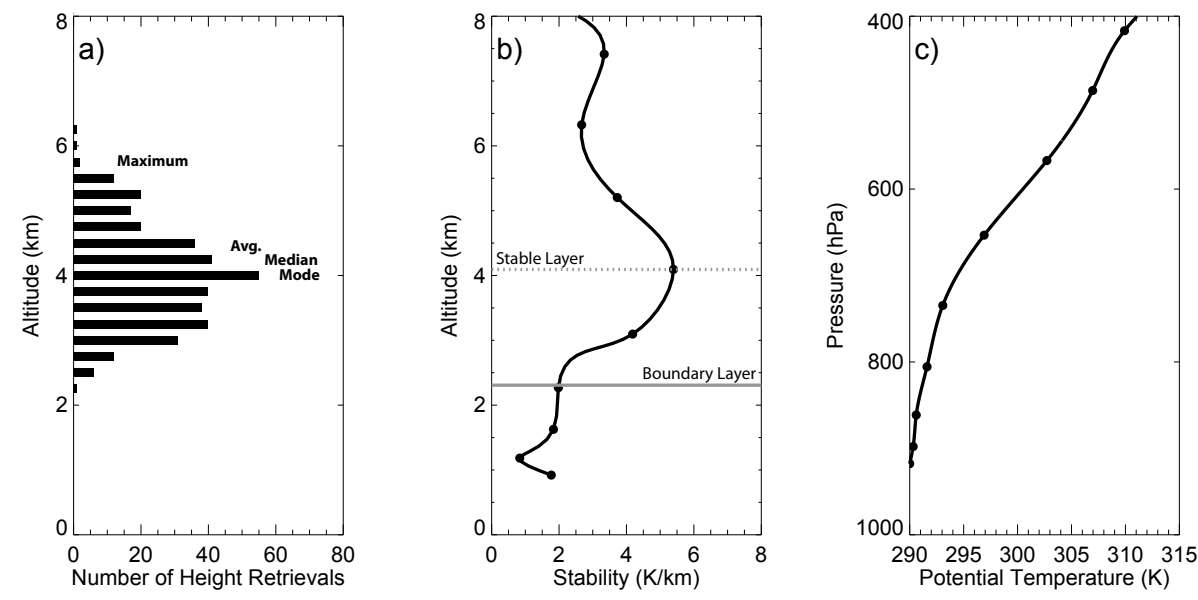

Fig. 4. Example of (a) vertical distribution of stereo-height pixels of a smoke plume, (b) atmospheric stability and (c) potential temperature profiles at the time and location of the smoke plume. Names to the right of the histogram in (a) indicate the altitudes of four plume height definitions: "maximum" is the best estimated maximum height, "avg." is the average height, "median" is the best estimated median height and "mode" is the mode height. The stereo-height pixels are given in $250 \mathrm{~m}$ bins. Horizontal gray lines indicate the stable layer height (dashed line) and the boundary layer height (solid line); black dots indicate the altitude levels in (b) and the GEOS pressure levels in (c).

$5250 \mathrm{~m}$ and bottom height of $3250 \mathrm{~m}$ ). For reference, the potential temperature profile with respect to the model pressure levels is shown in Fig. 4c.

We used the boundary layer height as an additional indication of atmospheric stability. We extracted the boundary layer heights from the GEOS fields. In the GEOS model, the height of the BL is given above the surface, and is defined as the height of the lowest layer in which the heat diffusivity falls below $2 \mathrm{~m}^{2} \mathrm{~s}^{-1}$. If the heat diffusivity in the layers is less than $2 \mathrm{~m}^{2} \mathrm{~s}^{-1}$, GEOS sets the BL height as the height of the surface layer (Lucchesi, 2007). Figure 4b shows the altitude of the BL as defined by GEOS. In this case, the BL is plotted above sea level for consistency with the stable layer height. The BL heights are provided every 3 hours, and these were interpolated to the time of the MISR overpass. As a result of the disparity between the GEOS definition of BL height and our definition of the stable layer height, in some cases the stable layer height is lower than the BL height. This type of atmospheric structure is unrealistic, and we excluded these cases from the analysis. This resulted in the removal of about $7 \%$ of the plume cases studied in Sects. 3.2.2 and 3.3.

We used the aggregated GEOS resolution of $2^{\circ}$ latitude by $2.5^{\circ}$ longitude with $6 \mathrm{~h}$ (and $3 \mathrm{~h}$ ) time steps, as this is the typical spatial and temporal resolution used in global CTMs. The coarse spatial resolution may introduce uncertainty in the atmospheric stability calculation. The stability profiles derived from GEOS data were compared to those from a high-resolution model, the Brazilian adaptation of the Regional Atmospheric Modeling System (BRAMS) (Pielke et al., 1992; Cotton et al., 2003; Sanchez-Ccoyllo et al., 2006) applied to North America, as described by Miller et al. (2008). This test was conducted by F.-Y. Leung (unpublished results) for the original 77 plumes from Alaska and the Yukon region in 2004 presented in Mazzoni et al. (2007). He found that the heights of the BL and the stable layers derived from the BRAMS fields agreed well with those from the GEOS fields. In addition, we compared the stability profiles derived from the GEOS-4 meteorological fields to those of the GEOS-5 original fields with higher horizontal and vertical resolution $\left(0.5^{\circ} \times 0.67^{\circ}\right.$ and 72 vertical levels $)$, for the plume data in 2006. Our work used the GEOS-4 and GEOS5 fields with resolution of $2^{\circ} \times 2.5^{\circ}$, as noted above. This test showed that in general the stability profiles derived from the GEOS $-50.5^{\circ} \times 0.67^{\circ}$ fields agreed well with those from the GEOS- 4 and GEOS-5 $2^{\circ} \times 2.5^{\circ}$ fields, although small differences were apparent: BL and stable layer height medians were $1260 \mathrm{~m}$ and $2600 \mathrm{~m}$ for GEOS-4 $\left(2^{\circ} \times 2.5^{\circ}\right)$, whereas they were $1460 \mathrm{~m}$ and $2410 \mathrm{~m}$ for GEOS-5 $\left(2^{\circ} \times 2.5^{\circ}\right)$ and $1500 \mathrm{~m}$ and $2340 \mathrm{~m}$ for GEOS-5 $\left(0.5^{\circ} \times 0.67^{\circ}\right)$. The difference in the results is mainly caused by the higher vertical resolution in GEOS-5 compared to GEOS-4, rather than the higher spatial resolution. However, this difference does not appear to significantly affect our major results: if we use GEOS-5 $\left(0.5^{\circ} \times 0.67^{\circ}\right)$, the relationship between plume height and atmospheric conditions does not change significantly, as discussed further below.

\section{Results and discussion}

Figure 5 presents an overview of the five years of MISR smoke plume and cloud heights. All median heights above the terrain observed by MISR are shown as a time series, and bar plots represent the distribution of the data by season and year. 


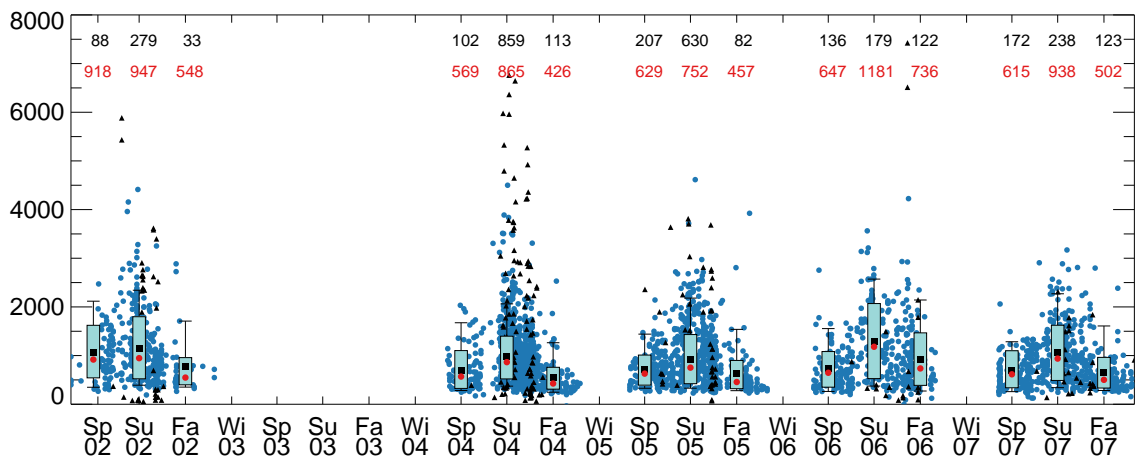

Fig. 5. Time series of plume heights observed by MISR over North America in 2002, and 2004-2007. Each data point represents the median height above the terrain for smoke plumes (in blue circles) and smoke clouds (in black triangles). Bar plots indicate the distribution of the smoke plume data for each season and year. The medians (red circles) and the means (black squares) are shown along with the central 67\% (light blue box) and the central 95\% (thin black lines). The number of observations (in black) and the median heights (in red) included in each distribution are given at the top of the plot.

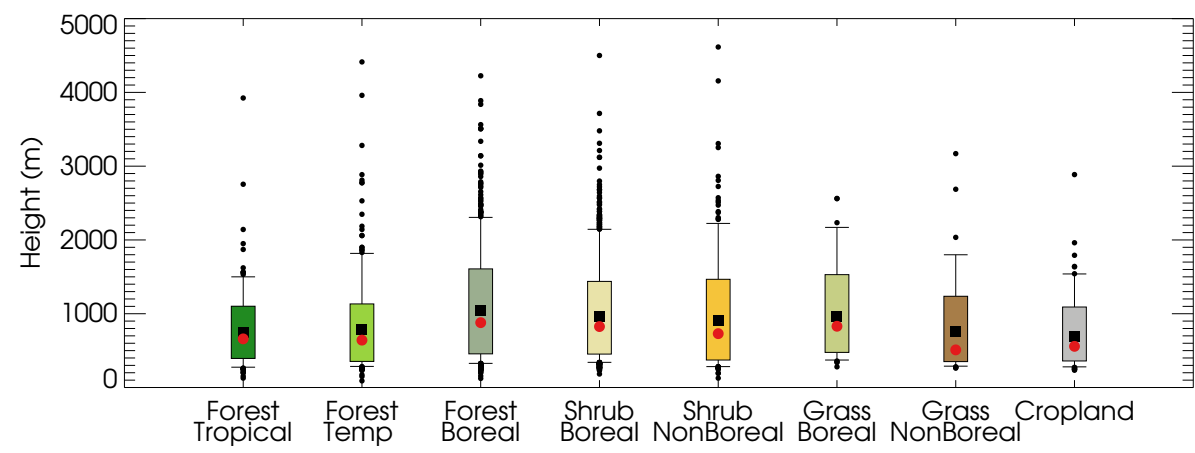

Fig. 6. Distribution of the median height above the terrain for smoke plumes in each biome (see Figure 3 for spatial distribution of the biomes). Bar plots indicate the distribution of the data. The medians (red circles) and the means (black squares) are shown along with the central $67 \%$ (color coded box) and the central 95\% (thin black lines). Data that fall outside the bar plots are plotted with black circles.

Significant variability is apparent in the data. A large number of factors may influence the plume height of smoke from fires. We analyze several aspects of the data: the elevation of smoke above different biomes in North America, the relationship between plume heights and atmospheric conditions, the relationship between plume height and fire characteristics, and the seasonal and inter-annual variability of plume heights. These factors are not mutually independent, but provide a framework for the discussion.

\subsection{Plume heights of fire smoke emissions}

Figure 6 displays the distribution of median heights above the terrain for smoke plumes in eight biomes for the five years of the study, and Fig. 3 shows the location of the biomes. We used the MODIS land cover map at $1 \times 1 \mathrm{~km}$ resolution (Friedl et al., 2002) to classify the MISR plumes in eight biomes: seasonally-dry tropical, temperate and boreal forest, boreal and non-boreal shrubland, boreal and non-boreal grassland and cropland. These biomes were chosen to allow significant numbers of plumes in the subsets for all years, while providing regions having different fire characteristics.
Table 1 summarizes the statistical parameters for the heights, lengths and thicknesses for all the plumes in each biome and for all observations.

The MISR plume heights range from a few hundred meters above the terrain to a maximum of about $5000 \mathrm{~m}$. The highest-altitude smoke plumes were detected over the boreal biomes, with median heights of about $850 \mathrm{~m}$, whereas the lowest median heights of about $530 \mathrm{~m}$ were found over cropland and grassland biomes in the contiguous US. Similar conclusions are found with other definitions of plume height. For example, the highest and lowest medians of the maximum plume heights were detected over boreal forests $(\sim 1200 \mathrm{~m})$ and croplands $(\sim 800 \mathrm{~m})$, respectively. As observed by MISR, smoke plumes over the boreal region were largest, with length and thickness median values of about $24 \mathrm{~km}$ and $940 \mathrm{~m}$, respectively, whereas plumes over cropland and seasonally-dry tropical forest were smallest, with length and thickness median values of $12 \mathrm{~km}$ and $550-640 \mathrm{~m}$, respectively. Variability in the observed plume heights and shapes is the result of many factors, as plumes can be influenced by the type of burning (e.g. prescribed burns versus 
Table 1. Summary of statical parameters for the MISR plume physical characteristics for each biome and for all observations ${ }^{\mathrm{a}}$.

\begin{tabular}{|c|c|c|c|c|c|c|c|}
\hline \multirow[t]{2}{*}{ Biomes } & \multicolumn{2}{|c|}{ Plume Median Height (m) } & \multicolumn{2}{|c|}{ Plume Length (km) } & \multicolumn{2}{|c|}{ Plume Thickness (m) } & \multirow[t]{2}{*}{$\mathrm{N}$} \\
\hline & Mean \pm SD & Median & Mean \pm SD & Median & Mean \pm SD & Median & \\
\hline Trop Forest & $744 \pm 438$ & 659 & $15.2 \pm 11.0$ & 12.1 & $752 \pm 514$ & 639 & 230 \\
\hline Temp Forest & $781 \pm 544$ & 642 & $22.9 \pm 18.8$ & 17.6 & $828 \pm 653$ & 669 & 399 \\
\hline Boreal Forest & $1040 \pm 646$ & 879 & $29.8 \pm 22.1$ & 23.5 & $1100 \pm 703$ & 952 & 872 \\
\hline Boreal Shrub & $961 \pm 558$ & 826 & $29.0 \pm 19.7$ & 23.6 & $1050 \pm 638$ & 931 & 1095 \\
\hline Non-Boreal Shrub & $910 \pm 650$ & 730 & $19.3 \pm 17.4$ & 14.2 & $883 \pm 752$ & 685 & 340 \\
\hline Boreal Grass & $969 \pm 538$ & 830 & $25.6 \pm 14.9$ & 23.7 & $1060 \pm 603$ & 940 & 91 \\
\hline Non-Boreal Grass & $776 \pm 755$ & 510 & $22.9 \pm 15.1$ & 19.3 & $763 \pm 677$ & 531 & 90 \\
\hline Cropland & $691 \pm 408$ & 558 & $14.5 \pm 8.3$ & 12.3 & $625 \pm 468$ & 547 & 158 \\
\hline All plumes & $922 \pm 586$ & 771 & $25.7 \pm 19.8$ & 20.0 & $970 \pm 670$ & 835 & 3367 \\
\hline
\end{tabular}

${ }^{a}$ Reported are mean and standard deviation (SD), median, and number $(\mathrm{N})$ of plume median height (m), plume length (km) and plume thickness (m).

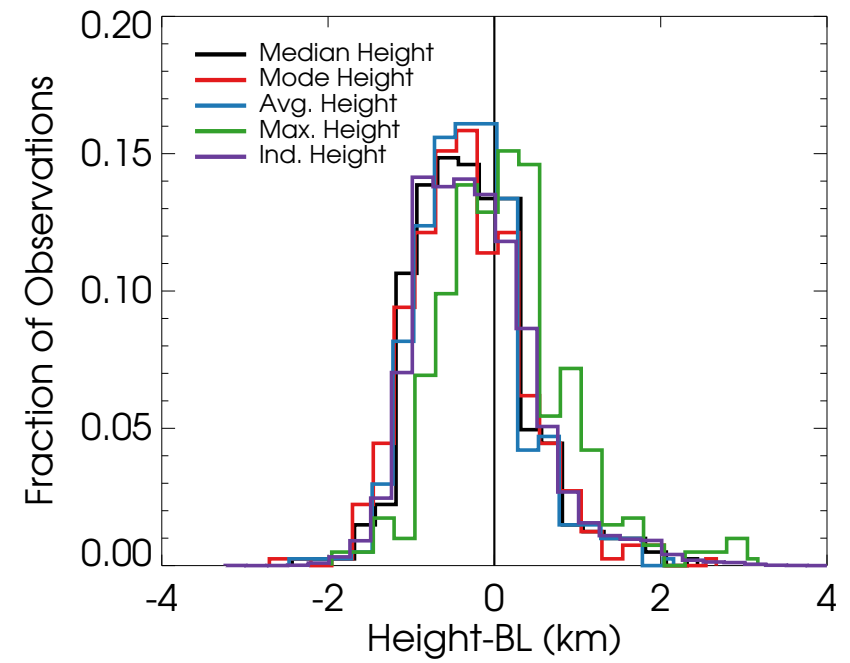

Fig. 7. Histogram of (Plume-BL height) for the 2002 North America plumes for five definitions of plume height: best estimated median height (black), mode height (red), average height (blue) and best estimated maximum height (green), for each plume, and all individual smoke height retrievals (purple).

wildfires), the type of fuel loading in a given biome, fire weather conditions (e.g. fuel moisture content), time of observation since ignition and meteorological conditions (e.g. Lavoue et al., 2000; Trentmann et al., 2006; Luderer et al., 2006; Freitas et al., 2007).

\subsection{Relationship between plume height and atmospheric conditions}

We first examine the relationship between smoke plume heights and boundary layer height. Second, we investigate the dependence of the smoke plume vertical distribution on the atmospheric stability.

\subsubsection{Plume heights relative to boundary layer height}

An analysis of the MISR observations from Alaska and Yukon Territories in the summer of 2004 showed that 5-18\% of the plumes were above the BL (Kahn et al., 2008). Here we assessed the fraction of plumes that inject smoke above the BL for the entire five years of data, using BL heights from the GEOS fields. The difference between the smoke plume heights and the BL height (Plume-BL height) was determined for five definitions of plume height, as described in Sect. 2.1.3.

Figure 7 shows results for 2002 as an example. The histograms of (Plume-BL height) are very similar for the median, mode, and average heights, as well as for the individual heights, with a small tail of the distribution showing plume heights above the BL. A larger fraction of the maximum plume heights are above the BL. Table 2 summarizes similar statistics of all definitions of plume height for each year. Table 2 also includes the statistics for the smoke cloud heights. Following Kahn et al. (2008), a smoke plume or cloud is considered to be in the free troposphere with high confidence when the (Plume-BL) height difference is $>500 \mathrm{~m}$, to account for errors in both the MISR heights and the GEOS BL heights. This criterion was designed to be conservative and, as a consequence, may omit some observations in the FT. For reference, we also include in Table 2 results when the (Plume-BL) height difference exceeds zero.

Table 2 shows that for any given year, the median, average, and mode of the plume heights give similar results, in terms of both the peak of the distribution of (Plume-BL height) and the fraction of plumes above the BL. Depending on the year, each of these definitions of plume height shows that the peak (defined by the median of the histogram) is $0.32-0.53 \mathrm{~km}$ below the BL, and that $4-12 \%$ of the plumes are above the BL. As expected, a higher fraction of maximum plume heights are above the BL, 15-28\%. Similarly, a higher percentage of the individual height pixels in all plumes are above the BL 
Table 2. Summary of the MISR smoke height statistics for 2002, 2004-2007 over North America ${ }^{\mathrm{a}}$.

\begin{tabular}{|c|c|c|c|c|c|c|}
\hline \multirow[b]{2}{*}{ Distribution } & \multicolumn{5}{|c|}{ Smoke Plumes } & \multirow{2}{*}{$\begin{array}{l}\text { Smoke } \\
\text { Clouds }^{b}\end{array}$} \\
\hline & 2002 & 2004 & 2005 & 2006 & 2007 & \\
\hline \multicolumn{7}{|c|}{ Median-PBL } \\
\hline Median & -0.32 & -0.32 & -0.47 & -0.38 & -0.48 & $-0.14(-0.34)$ \\
\hline$\%>0 \mathrm{~km}$ & 32 & 25 & 18 & 29 & 22 & $46(40)$ \\
\hline$\%>0.5 \mathrm{~km}$ & 10 & 7 & 5 & 12 & 7 & $35(32)$ \\
\hline $\mathrm{N}$ & 404 & 1074 & 919 & 437 & 533 & 227 \\
\hline \multicolumn{7}{|c|}{ Mode-PBL } \\
\hline Median & -0.34 & -0.36 & -0.48 & -0.39 & -0.53 & $-0.22(-0.41)$ \\
\hline$\%>0 \mathrm{~km}$ & 30 & 24 & 17 & 27 & 21 & 47 (39) \\
\hline$\%>0.5 \mathrm{~km}$ & 11 & 7 & 5 & 9 & 8 & $36(30)$ \\
\hline $\mathrm{N}$ & 404 & 1074 & 919 & 438 & 533 & 227 \\
\hline \multicolumn{7}{|c|}{$A v g-P B L$} \\
\hline Median & -0.32 & -0.32 & -0.47 & -0.39 & -0.48 & $-0.13(-0.34)$ \\
\hline$\%>0 \mathrm{~km}$ & 30 & 24 & 16 & 28 & 20 & $45(41)$ \\
\hline$\%>0.5 \mathrm{~km}$ & 11 & 6 & 4 & 10 & 7 & 34 (29) \\
\hline $\mathrm{N}$ & 404 & 1074 & 919 & 438 & 533 & 227 \\
\hline \multicolumn{7}{|c|}{$M a x-P B L$} \\
\hline Median & -0.2 & 0.01 & -0.17 & 0 & -0.19 & $1.4(0.39)$ \\
\hline$\%>0 \mathrm{~km}$ & 55 & 50 & 38 & 50 & 40 & $86(61)$ \\
\hline$\%>0.5 \mathrm{~km}$ & 25 & 23 & 15 & 28 & 18 & $71(48)$ \\
\hline $\mathrm{N}$ & 404 & 1174 & 919 & 438 & 438 & 227 \\
\hline \multicolumn{7}{|c|}{ All Ind-PBL } \\
\hline Median & -0.32 & -0.22 & -0.43 & -0.03 & -0.24 & $0.45(-0.17)$ \\
\hline$\%>0 \mathrm{~km}$ & 34 & 36 & 23 & 48 & 38 & $62(46)$ \\
\hline$\%>0.5 \mathrm{~km}$ & 14 & 16 & 9 & 25 & 17 & $49(36)$ \\
\hline $\mathrm{N}$ & 56477 & 98813 & 83111 & 33591 & 34323 & $66929(90714)$ \\
\hline
\end{tabular}

${ }^{\text {a }}$ Reported are median (in $\mathrm{km}$ ), number (N) of MISR observations and percentage of plumes above BL (\% $\left.>0 \mathrm{~km}\right)$ and above $500 \mathrm{~m}$ from the BL $(\%>0.5 \mathrm{~km})$.

${ }^{\mathrm{b}}$ Smoke cloud data is reported for filtered and non-filtered (in parentheses) (see text for explanation).

(9-25\%). An additional $12-22 \%$ (for the median, mode and average height definitions) and 22-30\% (for the maximum height definition) of the plumes are located between the BL and $500 \mathrm{~m}$ above. Overall, our results are consistent with those of Kahn et al. (2008) for the 2004 fire season over the boreal region (5\% above the BL for the median heights and $18 \%$ for the individual height pixels), and indicate that an important fraction of smoke plumes from the fires are injected above the BL at the time of the MISR overpass. As noted by Kahn et al. (2008), the best estimated median height (and similarly, the mode and average) is a more conservative definition of each plume height, as it reduces the importance of larger plumes and eliminates potential impacts from clouds that may be present above the smoke. Since the plumes are typically $835 \mathrm{~m}$ thick (median of all plumes in Table 1), using the strict criterion of $500 \mathrm{~m}$ implies that the entire thickness of the plume is, on average, well above the BL or, in other words, that a substantial amount of the smoke from these plumes gets injected into the FT.
It is important to note that the digitization protocol used for the MINX analysis intentionally excluded pyro-cumulus clouds, which could lead to significantly higher plumes triggered by the additional buoyancy from water vapor condensation. Hence, some plumes injected above the BL may not be captured in this data-base. This source of bias is not expected to significantly affect the results, as pyro-cumulus clouds develop fully late in the afternoon (Fromm et al., 2005; Damoah et al., 2006), after MISR overpass time. Visual inspection of the digitized MISR plumes in Alaska and the Yukon Territories for 2004 showed pyro-cumulus to be present in less than $3 \%$ of the plumes for which the smoke reached above $5500 \mathrm{~m}$ (Nelson et al., 2008b).

We evaluated the dependence of the fraction of plumes that inject smoke above the BL on the biome and fire season, as shown in Fig. 8 for the average of the mean, median, and mode heights. The figure includes the maximum of the fraction derived from the maximum and individual heights. It is clear that the fraction of plumes in the FT varies substantially from year to year within most biomes. For example, in shrubland biomes over the contiguous US the fraction in 


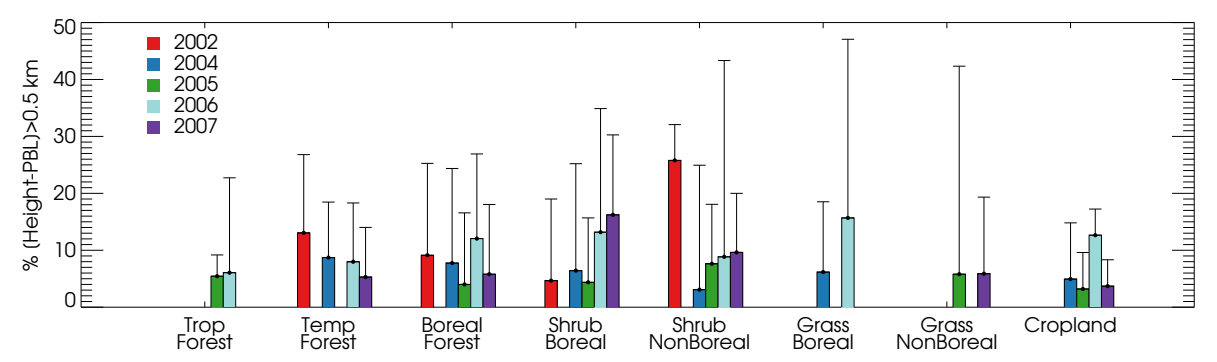

Fig. 8. Percentage of plumes above the BL for each year and biome. Bar plots indicate the mean of [Plume-BL Height] $>0.5 \mathrm{~km}$ for the median, mode and average heights, i.e. the mean of these statistics is shown; vertical black lines connect each mean to the maximum between the maximum and individual [Plume-BL Height] $>0.5 \mathrm{~km}$ values, i.e. the largest of all statistics calculated (see text for explanation). Distributions having fewer than 15 plumes are omitted.

the FT ranged from an average of 3\% in 2004 to $25 \%$ in 2002. This variability is associated mainly with year-to-year variations in fire intensity, as discussed in Sect. 3.4.2.

A relatively large fraction of plumes are above the BL in some years over grasslands and croplands (e.g. 13\% in 2006 over boreal grasslands). This larger fraction may be caused in part by the limited number of observations. The techniques used here to detect plumes have greater sensitivity over dark surfaces such as forests (Nelson et al., 2008b). For example, the number of plumes successfully digitized over boreal forests was 10 times larger than over grassland in the contiguous US, even though fires are easily detected by MODIS over cropland and grassland in the US (e.g. Ichoku et al., 2008; Pu et al., 2007). However, the smoke from fires over these biomes sometimes breaks through the BL and reaches high altitudes, as recently demonstrated in an analysis of Australian grassland fires using the more sensitive MISR research stereo-height retrieval algorithm, rather than the MINX tool (Mims et al., 2010).

As noted in Sect. 2.2, we evaluated the dependence of the results on the resolution of the GEOS meteorological fields for the plume data in 2006. We found that the fraction of the plumes that inject smoke above the BL does not change significantly: the percentage of the plumes located above the $\mathrm{BL}$ in 2006 is $12-28 \%$ for GEOS-4 $\left(2^{\circ} \times 2.5^{\circ}\right)$ (median and maximum heights; Table 2), whereas it is $9-22 \%$ for GEOS$5\left(0.5^{\circ} \times 0.67^{\circ}\right.$ and $\left.2^{\circ} \times 2.5^{\circ}\right)$.

Table 2 also shows the heights of smoke clouds derived from MISR observations relative to the BL. Smoke clouds generally represent a later stage of evolution of the smoke from fires, i.e. smoke that might have been lofted by advection or by convection unrelated to the fire itself, and possibly transported some distance from its source region (Nelson et al., 2008a). Table 2 shows that a larger fraction of smoke clouds reached the FT than smoke plumes $(\sim 35 \%$ versus 4 $12 \%$ for the averaged-type height definitions, and $71 \%$ versus $15-28 \%$ for the maximum height definition). It is likely that the smoke clouds are higher than the plumes because the latter are fresh emissions, and fires are not at their maximum intensity at the time of the MISR overpass. Smoke from the younger plumes may reach higher altitudes later in the day, as the fire intensity increases in the late afternoon over North America (Giglio et al., 2006; Ichoku et al., 2008) and advection driven by atmospheric processes has time to act on the smoke. It is interesting that the results from the smoke cloud analysis are more consistent with previous modeling studies, which showed that about half of fire emissions need to be injected above the BL to match $\mathrm{CO}$ and aerosol observations (e.g. Turquety et al., 2007; Leung et al., 2007; Generoso et al., 2007). We emphasize that the MISR smoke cloud observations - a relatively small dataset - may be biased towards dense smoke as it is easier to visualize by the MINX software operator, and that smoke cloud heights have larger uncertainties (up to $1 \mathrm{~km}$ ) than the smoke plume heights, as the former are not corrected for wind speed (Nelson et al., 2008b).

\subsubsection{Relationship between plume height and atmospheric stability}

Kahn et al. (2007) showed that aerosol plumes tend to concentrate within stable layers, regardless of the mixing mechanisms. Their work examined case studies of wildfire plumes, as well as dust plumes and the plume from a volcanic eruption. We analyzed the relationship between atmospheric stability and the MISR smoke plumes for the entire five-year dataset, and found that $86 \%$ of the plumes had stable layers associated with them; an example is shown in Fig. 4. For those plumes above the BL, less than $17 \%$ did not present a distinct stable layer. We expand here on previous work and investigate the degree to which the presence of stable layers in the atmosphere modulates the vertical distribution of the plumes. For this purpose, we divided the plumes located above the BL into two categories, those plumes with distinct stable layers present (i.e. "with stable layer") and those plumes without or with very weak stable layers (i.e. "without stable layer"). Table 3 summarizes the statistical parameters for each distribution for the median plume heights, all the individual height retrievals and the thickness of the plumes. For comparison, we also show the distribution of heights located within the BL (i.e. [Plume-BL height] $<250 \mathrm{~m}$ ). 


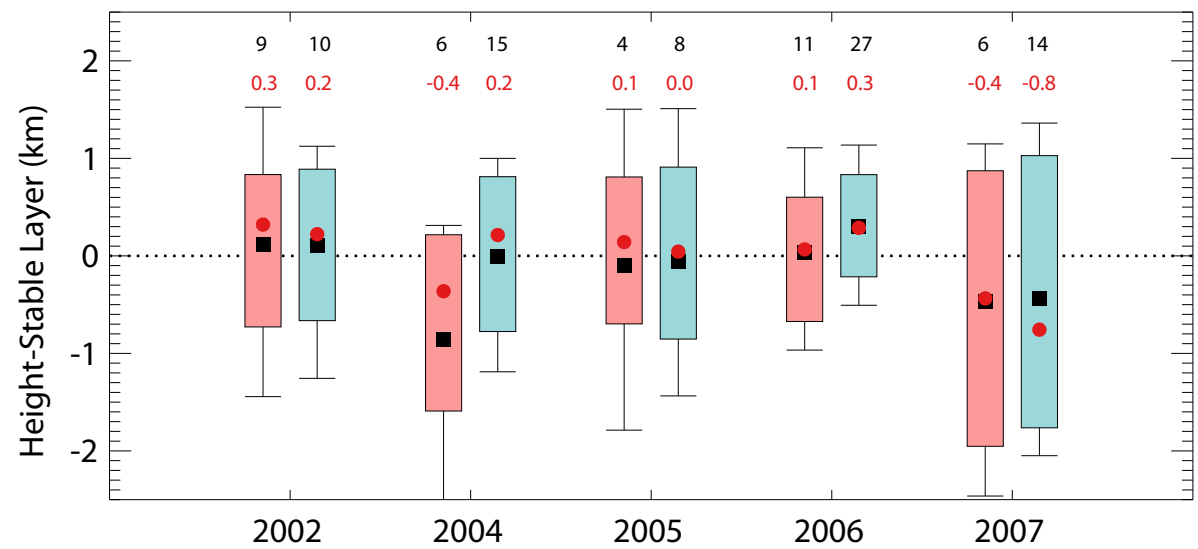

Fig. 9. Distribution of plume median heights (light red) and individual heights (light blue) located in the FT (see text for explanation) for plumes with stable layers. The medians (red circles) and the means (black squares) are shown along with the central 67\% (light blue or red box) and the central $90 \%$ (thin black lines). The percentage of observations (in black) and the median height(in km; red) included in each distribution are given above the bar plots.

Table 3. Statistics of plume height and thickness distribution above and below the boundary layer ${ }^{\mathrm{a}}$.

\begin{tabular}{lccccccccc}
\hline & \multicolumn{3}{c}{ Plume Median Heights } & \multicolumn{3}{c}{ Individual Height Retrievals } & \multicolumn{3}{c}{ Plume Thickness } \\
& Mean \pm SD & Median & N & Mean \pm SD & Median & N & Mean \pm SD & Median & N \\
\hline Above BL & & & & & & & & & \\
w/Stable Layer & $1980 \pm 696$ & 1880 & 186 & $2370 \pm 757$ & 2280 & 35173 & $1870 \pm 899$ & 1800 & 186 \\
w/o Stable Layer & $2580 \pm 815$ & 2490 & 38 & $2640 \pm 957$ & 2620 & 7253 & $2490 \pm 1150$ & 2790 & 38 \\
Below BL $^{\mathrm{b}}$ & $673 \pm 342$ & 591 & 2032 & $731 \pm 392$ & 642 & 158600 & $768 \pm 508$ & 664 & 2032 \\
\hline
\end{tabular}

${ }^{a}$ Reported are mean and standard deviation (SD), median, and number (N) of plume median heights, individual height retrievals and plume thickness, in meters.

b "Above BL" are observations when (Plume-BL height) $>500 \mathrm{~m}$; "Below BL" are observations when (Plume-BL height) $<250 \mathrm{~m}$.

We find that the mean height of plumes without stable layers is about $600 \mathrm{~m}$ higher than those with stable layers, $\sim 2600 \mathrm{~m}$ versus $\sim 2000 \mathrm{~m}$. A nonparametric Wilcoxon Sumrank and a Student t-test indicated that the two distributions and their means were significantly different at the 0.01 level of significance. Similarly, the difference in the individual height retrievals was about $350 \mathrm{~m}$, and this difference is also statistically significant. These results confirm that once the smoke from the fires reaches the FT, the ultimate plume rise is dominated by the presence of stratified layers in atmospheric stability, as proposed by Kahn et al. (2007).

To verify that the presence of stable layers was responsible for the lower heights of these plumes compared to those without such layers, we examined the difference between the median height of each plume and the altitude of the corresponding stable layer. The results are shown in Fig. 9. The median of these distributions of (Plume-stable layer height) is in the range -0.4 to $0.3 \mathrm{~km}$. Similar results are found if we use the individual pixel heights. As discussed in Sect. 2.2, these results are independent of the GEOS meteorological fields used in the analysis. For example, the median of the distri- bution of (Plume-stable layer height) in 2006 is $0.1 \mathrm{~km}$ for GEOS-4 $\left(2^{\circ} \times 2.5^{\circ}\right)$ (Fig. 9), whereas it is $0.0 \mathrm{~km}$ and $0.3 \mathrm{~km}$ for GEOS-5 $\left(2^{\circ} \times 2.5^{\circ}\right)$ and $\left(0.5^{\circ} \times 0.67^{\circ}\right)$, respectively.

Table 3 indicates that plumes with stable layers exhibit a median plume thickness of $1800 \mathrm{~m}$, whereas plumes without stable layers are more spread in the troposphere, with a median thickness of $2790 \mathrm{~m}$. Since the depth of the stable layers is typically $1877 \mathrm{~m}$ (median for all stable layers), it is clear that smoke plumes observed in the FT tend to remain confined within stable layers of the atmosphere when they are present.

\subsection{Dependence of plume height on fire characteristics}

We examined the relationship between MODIS FRP (i.e. a measure of the intensity of the fire) and the MISR plume heights, as shown in Fig. 10 for the entire data set. It is apparent that smoke plume heights are related to fire intensity in this log-log plot, but there is significant scatter $\left(r^{2}=0.2\right)$. Similar relationships were found for each of the eight biomes considered in the study. Several factors may contribute to this variability. 


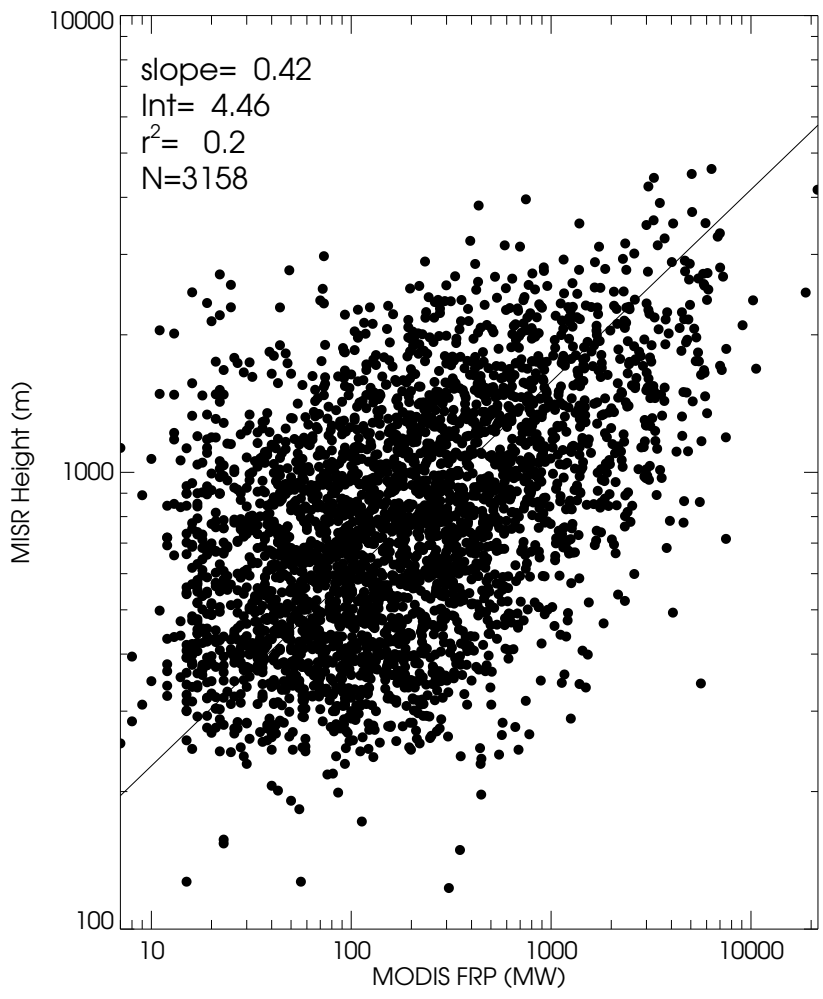

Fig. 10. Relationship between MISR median plume heights and MODIS total fire radiative power (FRP) for the 5-year data set. The regression line was calculated using a geometric mean (reduced major axis) two-sided regression technique (Ayers, 2001).

The MODIS FRP values associated with the MISR plumes are measures of instantaneous fire radiative power, and these FRP values may not represent the full dynamic state of the plume (Nelson et al., 2008a). Based on the wind speed determined from the MISR data and assuming a constant rate of transport after formation, a typical time for the development of the MISR plumes analyzed here is about $2 \mathrm{~h}$ (median for all plumes). Thus, a mismatch in MISR-MODIS timing can affect the plume height-FRP relationship. Also, the presence of dense smoke may lead to underestimates of the FRP values, and the FRP depends on the emissivity assumed in the retrieval, which may vary depending on the fire dynamics (e.g. smoldering versus flaming) (Kahn et al., 2007).

The atmospheric structure affects the ultimate plume rise, as shown in Sect. 3.2.2. To assess the effect of atmospheric conditions on the relationship between MODIS FRP and MISR plume height, we analyzed subsets of the data, taking into consideration the depth of the BL and the presence of stable layers. Figure 11 displays the results for four cases: plume observations within a shallow BL (i.e. $\mathrm{BL}<1000 \mathrm{~m}$ ) and within a deep BL (i.e. $\mathrm{BL}>1500 \mathrm{~m}$ ) and observations in the FT with the presence of a distinct stable layer and without or with a very weak stable layer. The mean and median MODIS FRP is given for each case. It is clear that those
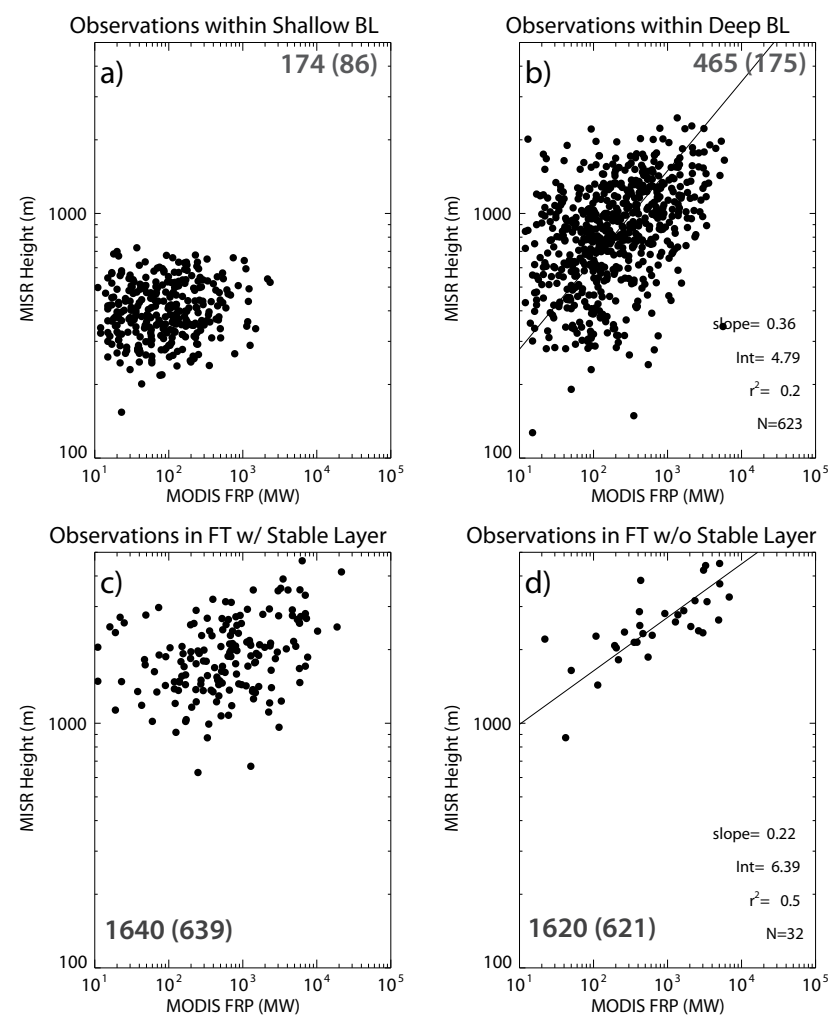

Fig. 11. Relationship between MISR observed medium plume heights and MODIS total fire radiative power for (a) observations in shallow BL, (b) observations in deep BL, (c) observations in FT with stable layer and (d) observations in FT without stable layer. (See text for explanation.) Regression lines for correlations with $r^{2}$ below 0.2 are not shown. The slope was calculated using a geometric mean (reduced major axis) two-sided regression technique (Ayers, 2001). Numerals in dark gray indicate the mean (median) of the MODIS FRP observations (MW) for each distribution.

plumes reaching the FT exhibit larger fire intensities than those located within the BL, with the median about 446553 MW higher. In addition, this analysis indicates that the depth of the BL and the existence of stratified layers in the atmosphere influence the plume height, independent of the fire intensity. For example, Fig. 11a and b show that no correlation exists with MODIS FRP for shallow BL heights $\left(r^{2}<0.1\right)$, whereas a better correlation is present for plumes with deeper BL heights $\left(r^{2}=0.2\right)$. Similarly, Fig. 11c shows that no correlation is found for the plumes located in the FT with a stable layer $\left(r^{2}<0.1\right)$, whereas a fairly good correlation $\left(r^{2}=0.5\right)$ is found for those plumes in the FT without a distinct stable layer (Fig. 11d). Thus, the depth of the BL and the presence of a stable layer influence the plume heights, and are partially responsible for the variability in the relationship between plume heights and fire intensity.

A preliminary study by Lavoue et al. (2000) proposed a linear relationship between fire intensity and plume height. However, their conclusion was based on observations of four 

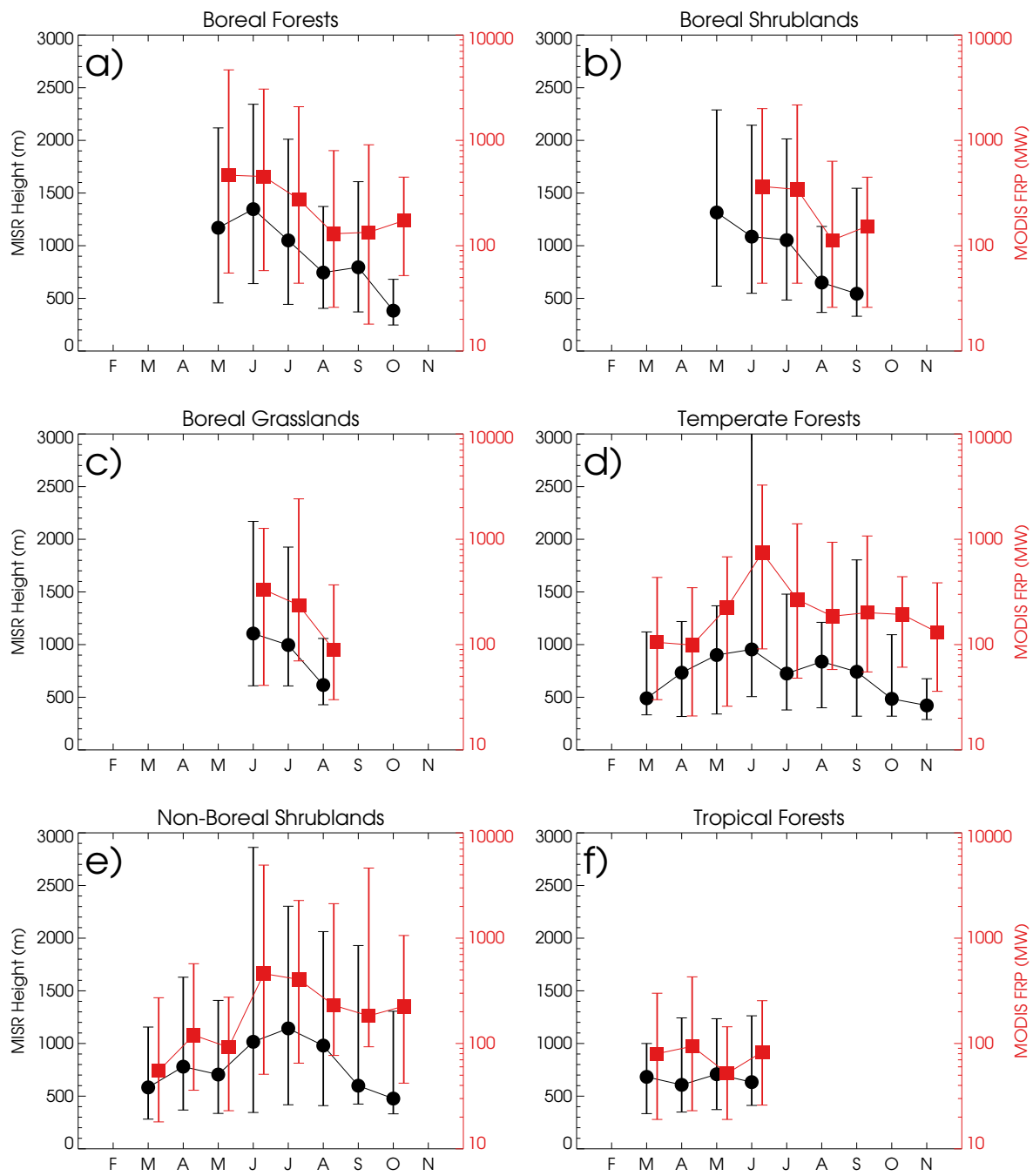

Fig. 12. Seasonal cycle of MISR plume median heights above the terrain (in solid black circles) and MODIS FRP (in solid red squares) for (a) boreal forest, (b) boreal shurbland, (c) boreal grassland, (d) temperate forest, (e) temperate shrubland and (f) seasonally-dry tropical forest. All years are included, and symbols represent monthly median values and vertical bars indicate the 10th and 90th percentile. Distributions with fewer than 15 points are omitted.

fires, and the fire intensity values were derived empirically from data for fuel consumption and the rate of fire spread. The extensive data set analyzed here shows the importance of both fire intensity and stability of the atmosphere in determining the plume height.

\subsection{Temporal variability of plume heights}

Here we examine the seasonality and inter-annual variability of the MISR plume height and the MODIS FRP for different biomes. This analysis uses the median heights of the individual plumes.

\subsubsection{Seasonal variation}

Figure 12 shows the annual cycle of plume heights and MODIS FRP for biomes with more than 20 observations per month. It is evident that there is a pronounced seasonal cycle of plume heights over the boreal biomes, with a minimum of the median plume heights of 400-650 $\mathrm{m}$ in SeptemberOctober and a maximum median of 1000-1400 m in MayJuly. Similarly, Fig. 12d-e show a clear seasonality in forest and shrubland biomes over the US, with minimum median heights of 400-800 m in October-March and maximum median heights of $900-1150 \mathrm{~m}$ in June-August. In contrast, over the seasonally-dry tropical forests, plumes were detected in significant numbers only during the dry season of March-June, with no seasonal variation (Fig. 12f). The median FRP was relatively low, 50-90 MW in these four months. In some cases the monthly medians may be influenced by the limited number of observations available in a given year. For example, monthly median values of plume height and MODIS FRP over temperate forests in June 

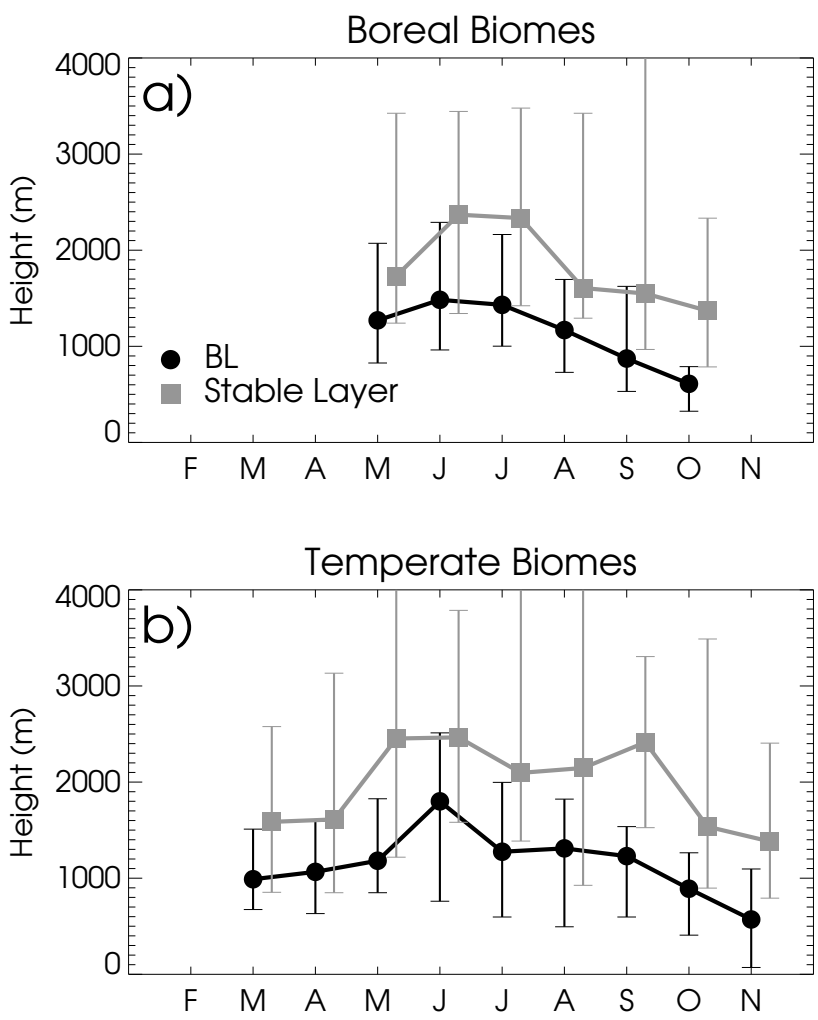

Fig. 13. Seasonal variability of BL heights (in solid black circles) and stable layer heights (in solid dark gray squares) for (a) boreal biomes and (b) temperate biomes. Symbols represent monthly median values and vertical bars indicate the 10th and 90th percentile.

(950 $\mathrm{m}$ and $750 \mathrm{MW}$ ) were much higher than in July-August $(\sim 800 \mathrm{~m}$ and $\sim 200 \mathrm{MW}$ ) because observations in June were dominated by 11 fires detected over Colorado, Oregon and Arizona in 2002, which were very intense as a result of unusually strong drought conditions (The Wilderness Society, 2003).

In Fig. 12a-f, the MODIS FRP shows a similar seasonal cycle to that of the plume heights in all the biomes except the seasonally-dry tropical forest. Not surprisingly, the annual variation of plume heights seems to be driven to a large extent by the annual cycle of fire intensity.

Several earlier studies found a seasonal variation in fire intensity over North America (e.g. Giglio et al., 2006; Ichoku et al., 2008; Zhang and Kondragunta, 2008; Pu et al., 2007). For example, based on multi-year FRP fluxes from the MODIS instrument on the Aqua satellite, Ichoku et al. (2008) showed that the months with peak fire intensity are JuneAugust over Alaska and Canada, and May-October and March-May over the western US and Mexico, respectively; no distinct peak months were detected over the eastern and central US, most likely because of the predominance of prescribed agricultural fires over these regions (Zhang and Kondragunta, 2008). Similarly, based on records of area burned and number of fires over North America, it has been shown
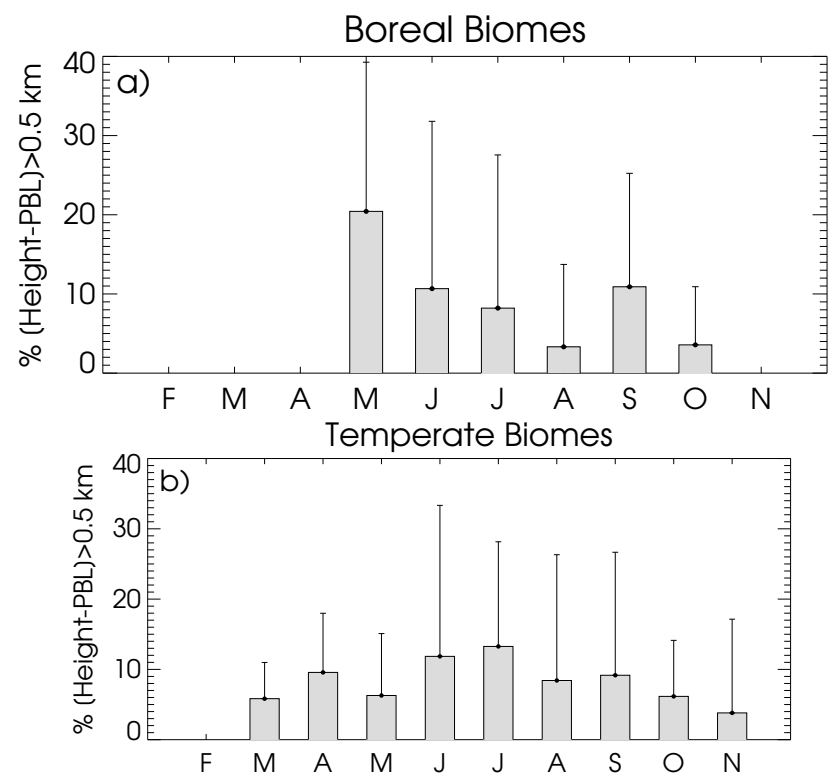

Fig. 14. Seasonal variation of the percentage of plumes above the BL for (a) boreal biomes and (b) temperate biomes. Bar plots indicate the mean of [Plume-BL Height] $>0.5 \mathrm{~km}$ for the median, mode and average height values; the vertical black lines connect each mean to the maximum between the maximum and individual [Plume-BL Height] $>0.5 \mathrm{~km}$ values (see text for explanation). Distributions with fewer than 15 plumes are omitted.

that the maximum peak of fires occurs in June and July (Stocks et al., 2003; Kasischke et al., 2005; Pu et al., 2007).

Seasonal changes in plume height may also be influenced by the seasonality in BL heights and in the occurrence of stable layers. Figure 13a-b show a distinct seasonal cycle for the $\mathrm{BL}$ and stable layer heights (those above the $\mathrm{BL}$ ) at the locations of the MISR plumes for boreal and temperate biomes (i.e. forest, shrubland and grassland for each). The BL height and, similarly, the stable layer heights are mostly driven by the surface temperature, which is closely related to the solar intensity cycle (Stull, 1988).

Figure $14 \mathrm{a}-\mathrm{b}$ shows that the fraction of plumes above the BL over both boreal and temperate biomes exhibits a seasonal cycle similar to that for the plume heights themselves, with the highest fraction of plumes above the BL in MayJuly and June-August, respectively. Thus, the seasonality in the BL height is not the major factor driving the seasonality in plume height, implying that the seasonality in fire intensity plays an important role.

Fire intensity is well recognized to be driven by fire weather conditions (e.g. Lobert and Warnatz, 1993). In the last decades, great efforts have been made to develop systems that use fire weather parameters (e.g. fuel moisture, relative humidity, temperature, wind speed) to predict fire behavior (e.g. rate of initial fire spread, head fire intensity) (e.g. Van Wagner, 1987; Burgan et al., 1997). Based on a large fire 

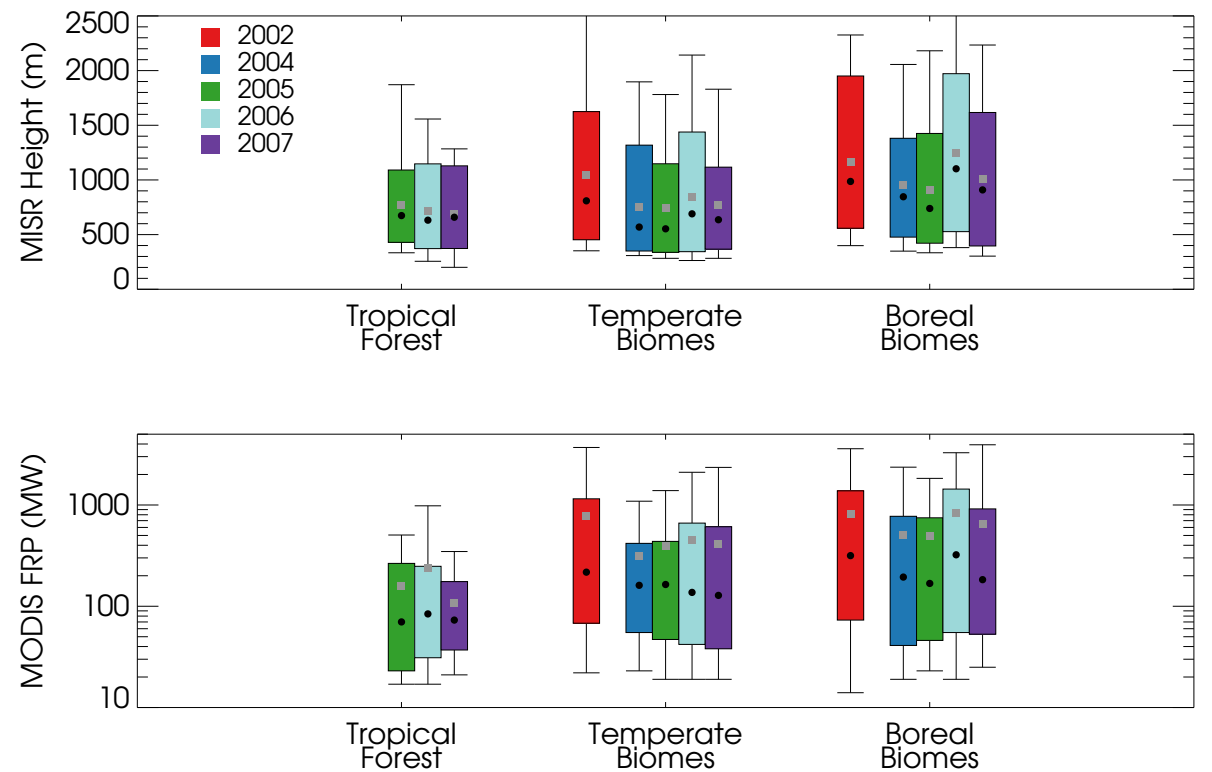

Fig. 15. Inter-annual variability of (a) MISR plume median heights above the terrain and (b) MODIS FRP, for seasonally-dry tropical forest, and temperate and boreal biomes. Bar plots indicate the distribution of the data for each year. The medians (black circles) and the means (gray squares) are shown along with the central 67\% (color coded box) and the central 95\% (thin black lines). Distributions with fewer than 25 data points are not shown. Note that year 2003 is left as a blank gap in the plot.

weather dataset over Canada, and using the Canadian Fire Weather Index (FWI) model, Amiro et al. (2004) showed that the maximum fire intensity (defined as head fire intensity, $\mathrm{MW} \mathrm{m}^{-1}$ ) tends to peak in June-July over the boreal cordillera and taiga shield ecozones (i.e. the regions where most of the MISR plumes are located over Canada). The increased fire intensity over these months is the result of an increase on both the total fuel available to burn and the initial spread index, which are functions of temperature, wind speed, relative humidity and rain accumulation. Similar results appear in our preliminary analysis of fire weather indexes using the Canadian FWI model at the location of the MISR plumes.

\subsubsection{Inter-annual variability}

Figure 15 displays the inter-annual variability of plume heights over seasonally-dry tropical forests, and temperate and boreal biomes. This classification captures approximately the variability of fires over Mexico, the contiguous US, and Alaska and Canada, respectively. The inter-annual variability of MODIS FRP is also shown in Fig. 15b. From Fig. $15 \mathrm{a}$, it is clear that the plume heights vary from year-toyear over the boreal and temperate biomes, as mentioned in Sect. 3.2.1, with all percentiles and medians larger in 2002 and 2006. In contrast, no inter-annual variability is observed over tropical forests. Figure 15b shows a direct relationship between the year-to-year changes in plume heights and in the MODIS FRP over the boreal region: the highest annual median MODIS FRP values coincide with the highest an- nual median MISR height values. However, this inter-annual MODIS FRP-MISR height relationship is not apparent for the temperate biomes.

One might expect that those years with the largest fire intensity would coincide with the most active fire seasons. However, this is not the case. According to the US and Canada National Interagency Fire Center (http://www.cidi. org/wildfire and http://www.ciffc.ca), the most active fire seasons were years 2006 and 2007 over the contiguous US, with about 3.9 and 3.6 million hectares burned, respectively, and 2004 over Alaska and Canada, with about 6.0 million hectares burned. The mismatch among area burned, MODIS FRP and MISR plume height is not surprising. Area burned is reported as totals by state or province, and the MISR plume climatology, although extensive, does not include plumes from all seasons and regions, as noted above. In addition, large, intense fires typically develop during late afternoon (Damoah et al., 2006), and plumes from these fires are not always observed by MISR.

\section{Summary and conclusions}

Observations of aerosol plume heights and fire radiative power made from the MISR and MODIS instruments, respectively, over North America during five burning seasons were used to characterize the magnitude and variability of smoke plume heights over various biomes, and to assess the degree to which local atmospheric and fire conditions contribute to this variability. 
Analysis of the MISR plume climatology shows that plume heights are highly variable over different North American biomes, with heights ranging from a few hundred meters up to about $5000 \mathrm{~m}$ above the terrain, when observed between 11:00 and 14:00 local time. The highest and largest plumes were detected over the boreal region (median values of $\sim 850 \mathrm{~m}$ height, $24 \mathrm{~km}$ length and $940 \mathrm{~m}$ thickness), whereas the lowest and smallest plumes were found over cropland and grassland fires in the contiguous US (median values of $\sim 530 \mathrm{~m}$ height, $12 \mathrm{~km}$ length and $550-640 \mathrm{~m}$ thickness). Using GEOS BL heights, we determined that $4-12 \%$ of the plumes were injected above the BL (i.e. Plume-BL height $>500 \mathrm{~m}$ ), depending on the year; an additional 12 $22 \%$ of the plumes were located between the BL and $500 \mathrm{~m}$ above. The fraction of plumes above the BL varied substantially from year to year within each biome. This result is consistent with that of Kahn et al. (2008), in which 5\% of plumes were injected above the BL over Alaska and the Yukon Territories in 2004, and indicates that an important fraction of smoke plumes from the fires was injected above the BL at the time of MISR overpass. The actual plume height and the fraction of smoke plumes above the BL may grow even larger later in the afternoon, as the MISR plume heights are limited to the overpass time of the Terra satellite, when fires have not yet reached their maximum intensity.

Analysis of MISR smoke clouds, which constitute a later stage of smoke plume evolution, shows that the fraction above the BL is much larger $(\sim 35 \%)$. This result was more consistent with previous modeling studies, which showed that more than $50 \%$ of the emissions from extra-tropical fires need to be injected above the BL to match downwind $\mathrm{CO}$ and aerosol observations (Leung et al., 2007; Turquety et al., 2007; Generoso et al., 2007). We suggest that smoke clouds are at higher elevations, on average, than plumes because smoke from the younger plumes may reach higher altitudes later in the day, as fire intensity increases in the late afternoon (Giglio et al., 2006; Ichoku et al., 2008), or due to advection driven by atmospheric motions unrelated to the fire itself, that have more time to act on the smoke.

Associated simultaneous measurements of MODIS FRP indicate a clear connection between radiative fire heat flux and plume height (on a log-log scale). Plumes that break through the BL and reach the FT exhibit larger FRP values than those that remain in the BL, with the median about 500 MW higher (621-639 MW versus 86-175 MW). The ultimate rise of the plume and vertical distribution of the smoke in the FT was dominated by the presence of stable layers in the atmosphere; most plumes ( $>83 \%)$ located above the $\mathrm{BL}$ are associated with a stable atmospheric layer. Plumes located in the FT without or with weak stable layers reach higher elevations than those with distinct stable layers, 2600 versus $2000 \mathrm{~m}$ (reported median of heights). In addition, the plumes without stable layers were more vertically spread-out (median thickness of $2790 \mathrm{~m}$ ) relative to those plumes with stable layers (median thickness of $1800 \mathrm{~m}$ ). Since the typical stable layer depth is $1877 \mathrm{~m}$, similar to the plume thickness, and the median of the (plume-stable layer height) distribution was near zero, these results confirm that smoke plumes tend to get trapped within stable layers in the FT when they are present, as proposed by Kahn et al. (2007).

The MISR plume data reveal the presence of a welldefined seasonal cycle in the plume heights in boreal and temperate biomes, with larger heights during the summer months. The higher plumes in summer were not simply a result of higher BL heights, as the fraction of plumes above the BL tends to be larger in summer. Using MODIS FRP measurements, we determined that larger summertime heights were the result of higher fire intensities. We attributed the increased fire intensity during these months to more severe fire weather (Amiro et al., 2004). The inter-annual variability of plume heights is also related to changes in fire intensity, in particular in boreal biomes. As a result of climate change, more frequent and more severe wildfires are expected, which may result in an increase in wildfire emissions (Stocks et al., 1998; Flannigan et al., 2000; Spracklen et al., 2009) and also in the altitude at which these emissions are injected into the atmosphere. Therefore, the influence of wildfire emissions may become even more extensive in the future.

Global chemical transport models typically assume that emissions travel upward to a constant, pre-fixed altitude, using an empirical relationship such as that given in Lavoue et al. (2000), or emissions are uniformly distributed up to a certain height or with a fixed fraction above the BL (e.g. Lamarque et al., 20003; Turquety et al., 2007). These simple parameterizations are independent of the atmospheric stability structure and dynamical heat flux.

Our analysis demonstrates the significant variability in smoke injection heights and the important effect of both the buoyancy generated by the fire and the atmospheric structure in determining the ultimate rise of these emissions. Neglecting these effects is a potential source of error in CTM simulations. Plume-resolving models can take into account the buoyancy driven by the fire heat, combined with finer-scale meteorology processes (e.g. Freitas et al., 2006; Trentmann et al., 2006). The 1-D plume-rise model presented by Freitas et al. (2006) has been embedded in a regional model (Freitas et al., 2007) and in a global model (Guan et al., 2008) for exploratory case studies in the tropics. However, the validation of 1-D plume-rise models has focused to date on case studies, usually of particular pyro-convective events. The MISR plume data provide an opportunity for extensive validation of such plume rise models, and we are presently using the MISR data to evaluate the model of Freitas et al. (2006).

Recently, Chen et al. (2009) used the observed MISR plume heights over the boreal region in 2004 (Kahn et al., 2008) to derive fire emission injection heights for the global GEOS-Chem chemical transport model. The match between the model and surface aerosol and CO measurements near the fire source was improved by using the MISR-derived injection heights. However, this did not significantly enhance 
the accuracy of the simulation in downwind regions, possibly because the injection heights used were those reached by the plumes at the MISR overpass time. In current work, we are exploring the relationship between the MISR plume height, radiative energy flux observed by MODIS and atmospheric stability structure using a 1-D plume-rise model. We are also developing a simple parameterization of injections heights based on insights from analysis of the MISR plume heights.

Acknowledgements. This worked was supported by the National Science Foundation, grant ATM0554804, and by STAR Research Assistance Agreement No. RD-83227501-0 awarded by the US Environmental Protection Agency (EPA). This publication has not been formally reviewed by the EPA. The views expressed in this document are solely those of authors and the EPA does not endorse any products or commercial services mentioned in this publication. Part of this research was carried out by the Jet Propulsion Laboratory, California Institute of Technology, under contract with the National Aeronautics and Space Administration (NASA). We thank Charles Ichoku for helpful discussions about MODIS fire radiative power; the work of many summer students who contributed to the digitizing effort at the Jet Propulsion Laboratory is gratefully acknowledged.

Edited by: I. Aben

\section{References}

Amiro, B. D., Logan, K., Wotton, B., Flannigan, M., Todd, J., Stocks, B., and Martell, D.: Fire weather index system components of large fires in the Canadian boreal forest, Int. J. Wildland Fire, 13, 391-400, 2004.

Andreae, M. and Merlet, P.: Emissions from trace gases and aerosols from biomass burning, Global Biogeochem. Cycles, 15, 955-966, 2001.

Ayers, G.: Comment on regression analysis of air quality data, Atmos. Environ., 35, 2423-2425, 2001.

Blake, D. R., T. W. Smith, J., Chan, T.-Y., Whipple, W. J., and Rowland, F. S.: Effects of biomass burning on summertime nonmethane hydrocarbon concentrations in the Canadian wetlands, J. Geophys. Res., 99, 1699-1719, 1994.

Bloom, S., da Silva, A., Dee, D., Bosilovich, M., Chern, J.-D., Pawson, S., Schubert, S., Sienkiewicz, M., and Stajner, I.: Documentation and validation of the Goddard Earth Observing System (GEOS) Data Assimilation System - Version 4 .Technical report series on Global Modeling and Data Assimilation, Tech. Rep. NASA/TM20057104606, Vol. 26, 2005.

Burgan, R. E., Andrews, P., Bradshaw, L., Chase, C., Hartford, R., and Latham, D.: WFAS: Wildland Fire Assessment System, Tech. Rep. Fire Management Notes, 57(2), 14-17, 1997.

Chen, Y., Li, Q., Randerson, J. T., Lyons, E. A., Kahn, R. A., Nelson, D. L., and Diner, D. J.: The sensitivity of CO and aerosol transport to the temporal and vertical distribution of North American boreal fire emissions, Atmos. Chem. Phys., 9, 6559-6580, 2009 ,

http://www.atmos-chem-phys.net/9/6559/2009/.

Colarco, P. R., Schoeberl, M. R., Doddridge, B. G., Marufu, L. T., Torres, O., and Welton, E. J.: Transport of smoke from Cana- dian forest fires to the surface near Washington, D.C.: Injection height, entrainment, and optical properties, J. Geophys. Res., 109, D06203, doi:10.1029/2003JD004248, 2004.

Cotton, W. R., Pielke, R. A., Walko, R. L., Liston, G., Tremback, C. J., Jiang, H., McAnelly, R. L., Harrington, J. Y., Nicholls, M. E., Carrio, G. G., and McFadden, J. P.: RAMS 2001: Current status and future directions, Meteorol. Atmos. Phys., 82, 5-29, 2003.

Damoah, R., Spichtinger, N., Forster, C., James, P., Mattis, I., Wandinger, U., Beirle, S., Wagner, T., and Stohl, A.: Around the world in 17 days - hemispheric-scale transport of forest fire smoke from Russia in May 2003, Atmos. Chem. Phys., 4, 13111321, 2004, http://www.atmos-chem-phys.net/4/1311/2004/.

Damoah, R., Spichtinger, N., Servranckx, R., Fromm, M., Eloranta, E. W., Razenkov, I. A., James, P., Shulski, M., Forster, C., and Stohl, A.: A case study of pyro-convection using transport model and remote sensing data, Atmos. Chem. Phys., 6, 173-185, 2006, http://www.atmos-chem-phys.net/6/173/2006/.

de Gouw, J. A., Warneke, C., Stohl, A., Wollny, A. G., Brock, C. A., Cooper, O. R., Holloway, J. S., Trainer, M., Fehsenfeld, F. C., Atlas, E. L., Donnelly, S. G., Stroud, V., and Lueb, A.: Volatile organic compounds composition of merged and aged forest fire plumes from Alaska and western Canada, J. Geophys. Res., 111, D10303, doi:10.1029/2005JD006175, 2006.

Diner, D. J., Beckert, J., Reilly, T., Bruegge, C., Conel, J., Kahn, R., Martonchik, J., Ackerman, T., Davies, R., Gerstl, S., Gordon, H., Muller, J.-P., Myneni, R., Sellers, P., Pinty, B., and Verstraete, M.: Multi-angle Imaging SpectroRadiometer (MISR) instrument description and experiment overview, IEEE Trans. Geosci. Remote Sens., 36, 1072-1087, 1998.

Dirksen, R. J., Boersma, K. F., de Laat, A. T. J., Stammes, P., van der Werf, G. R., Val Martin, M., , and Kelder, H. M.: An aerosol boomerang: rapid around-the-world transport of smoke from the December 2006 Australian forest fires observed from space, J. Geophys. Res., 114, D21201, doi:10.1029/2009JD012360, 2009.

Duck, T. J., Firanski, B. J., Millet, D. B., Goldstein, A. H., A1lan, J., Holzinger, R., Worsnop, D. R., White, A. B., Stohl, A., Dickinson, C. S., and van Donkelaar, A.: Transport of forest fire emissions from Alaska and the Yukon Territory to Nova Scotia during summer 2004, J. Geophys. Res., 112, D10S44, doi:10.1029/2006JD007716, 2007.

Flannigan, M., Stocks, B., and Wotton, B.: Climate change and forest fires, Sci. Tot. Env., 262, 221-229, 2000.

Forster, P., Ramaswamy, V., Artaxo, P., Berntsen, T., Betts, R., Fahey, D. W., Haywood, J., Lean, J., Lowe, D., Myhre, G., Nganga, J., Prinn, R., Raga, G., Schulz, M., and Dorland, R. V.: Changes in atmospheric constituents and in radiative forcing, in: Climate Change 2007: The Physical Science Basis. Contribution of Working Group I to the Fourth Assessment Report of the Intergovernmental Panel on Climate Change, Cambridge University Press, Cambridge, United Kingdom and New York, NY, USA, 2007.

Freitas, S. R., Longo, K. M., and Andreae, M. O.: Impact of including the plume rise of vegetation fires in numerical simulations of associated atmospheric pollutants, Geophys. Res. Lett., 33, L17808, doi:10.1029/2006GL026608, 2006.

Freitas, S. R., Longo, K. M., Chatfield, R., Latham, D., Silva Dias, 
M. A. F., Andreae, M. O., Prins, E., Santos, J. C., Gielow, R., and Carvalho Jr., J. A.: Including the sub-grid scale plume rise of vegetation fires in low resolution atmospheric transport models, Atmos. Chem. Phys., 7, 3385-3398, 2007,

http://www.atmos-chem-phys.net/7/3385/2007/.

Friedl, M. A., McIver, D. K., Hodges, J. C. F., Zhang, X., Muchoney, D., Strahler, A. H., Woodcock, C. E., Gopal, S., A. Schnieder, A. C., Baccini, A., Gao, F., and Schaaf, C.: Global land cover from MODIS: Algorithms and early results, Remote Sens. Environ., 83, 135-148, 2002.

Fromm, M., Alfred, J., Hoppel, K., Hornstein, J., Bevilacqua, R., Shettle, E., Servranckx, R., Li, Z., , and Stocks, B.: Observations of Boreal Forest Fire Smoke in the Stratosphere by POAM III, SAGE II, and Lidar in 1998, Geophys. Res. Lett., 27, 1407-1410, 2000.

Fromm, M., Bevilacqua, R., Servranckx, R., Rosen, J., Thayer, J. P., Herman, J., and Larko, D.: Pyro-cumulonimbus injection of smoke to the stratosphere: Observations and impact of a super blowup in northwestern Canada on 3-4 August 1998, J. Geophys. Res., 110, 1-16, doi:10.1029/2004JD005350, 2005.

Generoso, S., Bey, I., Atti, J.-L., and Bron, F.-M.: A satelliteand model-based assessment of the 2003 Russian fires: Impact on the Arctic region, J. Geophys. Res., 112, D15302, doi:10.1029/2006JD008344, 2007.

Giglio, L., Descloitres, J., Justice, C. O., and Kaufman, Y. J.: An enhanced contextual fire detection algorithm for MODIS, Remote Sens. Environ., 87, 273-282, 2003.

Giglio, L., Csiszar, I., and Justice, C. O.: Global distribution and seasonality of active fires as observed with the Terra and Aqua Moderate Resolution Imaging Spectroradiometer (MODIS) sensors, J. Geophys. Res., 111, G02016, doi:10.1029/2005JG000142, 2006.

Goode, J. G., Yokelson, R. J., Ward, D. E., Susott, R. A., Babbitt, R. E., Davies, M. A., and Hao, W. M.: Measurements of excess $\mathrm{O}_{3}, \mathrm{CO}, \mathrm{CO}_{2}, \mathrm{CH}_{4}, \mathrm{C}_{2} \mathrm{H}_{6}, \mathrm{C}_{2} \mathrm{H}_{4}, \mathrm{HCN}, \mathrm{NO}, \mathrm{NH}_{3}, \mathrm{HCOOH}$, $\mathrm{CH}_{3} \mathrm{COOH}, \mathrm{HCHO}$ and $\mathrm{CH}_{3} \mathrm{OH}$ in 1997 Alaskan biomass burning plumes by airborne Fourier transform infrared spectroscopy (AFTIR), J. Geophys. Res., 105, 22147-22166, 2000.

Guan, H., Chatfield, R. B., Freitas, S. R., Bergstrom, R. W., and Longo, K. M.: Modeling the effect of plume-rise on the transport of carbon monoxide over Africa with NCAR CAM, Atmos. Chem. Phys., 8, 6801-6812, 2008,

http://www.atmos-chem-phys.net/8/6801/2008/.

Holton, J. R.: An Introduction to Dynamic Meteorology, Elsevier New York, 1992.

Honrath, R. E., Owen, R. C., Val Martin, M., Reid, J. S., Lapina, K., Fialho, P., Dziobak, M. P., Kleissl, J., and Westphal, D. L.: Regional and hemispheric impacts of anthropogenic and biomass burning emissions on summertime $\mathrm{CO}$ and $\mathrm{O}_{3}$ in the North Atlantic lower free troposphere, J. Geophys. Res., 109, D24310, doi:10.1029/2004JD005147, 2004.

Hyer, E. J., Allen, D. J., and Kasischke, E. S.: Examining injection properties of boreal forest fires using surface and satellite measurements of CO transport, J. Geophys. Res., 112, D18307, doi:10.1029/2006JD008232, 2007.

Ichoku, C., Giglio, L., Wooster, M. J., and Remner, L.: Global characterization of biomass-burning patterns using satellite measurements of fire radiative energy, Remote Sens. Environ., 112, 2950-2962, 2008.
Justice, C. O., Giglio, L., Korontzi, S., Owens, J., Morisette, J., Roy, D., Descloitres, J., Alleaume, S., Petitcolin, F., and Kaufman, Y.: The MODIS fire products, Remote Sens. Environ., 83, 244-262, 2002.

Kahn, R. A., Li, W.-H., Moroney, C., Diner, D. J., Martonchik, J. V., and Fishbein, E.: Aerosol source plume physical characteristics from space-based multi-angle imaging, J. Geophys. Res., 112, D11205, doi:10.1029/2006JD007647, 2007.

Kahn, R. A., Chen, Y., Nelson, D. L., Leung, F.-Y., Li, Q., Diner, D. J., and Logan, J. A.: Wildfire Smoke Injection Heights Two Perspectives from Space, Geophys. Res. Lett., 35, L04809, doi:10.1029/2007GL032165, 2008.

Kasischke, E. S., Hyer, E. J., Novelli, P. C., Bruhwiler, L. P., French, N. H. F., Suckhinin, A. I., Hewson, J. H., and Stocks, B. J.: Influences of boreal fire emissions on Northern Hemisphere atmospheric carbon and carbon monoxide, Global Biogeochem. Cycles, 19, GB1012, doi:10.1029/2004GB002300, 2005.

Kaufman, Y., Ichoku, C., Giglio, L., Korontzi, S., Chu, D. A., Hao, W. M., Li, R.-R., and Justice, C. O.: Fires and smoke observed from the Earth Observing System MODIS instrumentProducts, validation, and operational use, Int. J. Remote Sens., 24, 17651781, 2003.

Kaufman, Y. J., Justice, C. O., Flynn, L. P., Kendall, J. D., Prins, E. M., Giglio, L., Ward, D. E., Menzel, W. P., and Setzer, A. W.: Potential global fire monitoring from EOS-MODIS, J. Geophys. Res., 103, 32315-32338, 1998.

Labonne, M., Breon, F.-M., and Chevallier, F.: Injection height of biomass burning aerosols as seen from a spaceborne lidar, Geophys. Res. Lett., 34, L11806, doi:10.1029/2007GL029311, 2007.

Lamarque, J.-F., Edwards, D. P., Emmons, L. K., Gille, J. C., Wilhelmi, O., Gerbig, C., Prevedel, D., Deeter, M. N., Warner, J., Ziskin, D. C., Khattatov, B., Francis, G. L., Yudin, V., Ho, S., Mao, D., Chen, J., and Drummond, J. R.: Identification of CO plumes from MOPITT data: Application to the August 2000 Idaho-Montana forest fires, Geophys. Res. Lett., 30(13) 1688, doi:10.1029/2003GL017503, 2003.

Lavoue, D., Liousse, C., Cachier, H., Stocks, B. J., and Goldammer, J. G.: Modeling of carbonaceous particles emitted by boreal and temperate wildfires at northern latitudes, J. Geophys. Res., 1035, 26871-26890, 2000.

Leung, F.-Y. T., Logan, J. A., Park, R., Hyer, E., Kasischke, E., Streets, D., and Yurganov, L.: Impacts of enhanced biomass burning in the boreal forests in 1998 on tropospheric chemistry and the sensitivity of model results to the injection height of emissions, J. Geophys. Res., 112, D10313, doi:10.1029/2006JD008132, 2007.

Lobert, J. M. and Warnatz, J.: Emissions from the combustion process in vegetation, in: Fire in the environment: The ecological, atmospheric and climatic importance of vegetation fires, edited by Crutzen, P. J. and Goldammer, J. G., John Wiley and Sons Ltd., West Sussex, England, 1993.

Lucchesi, R.: File Specification for GEOS-5 DAS Gridded Output Global Modeling and Assimilation Office Version 6.3, Goddard Space Flight Center, Greenbelt, Maryland. Published on the web, http://gmao.gsfc.nasa.gov/operations/GEOS5_V1_File_ Specification.pdf, 2007.

Luderer, G., Trentmann, J., Winterrath, T., Textor, C., Herzog, M., Graf, H. F., and Andreae, M. O.: Modeling of biomass smoke injection into the lower stratosphere by a large forest fire (Part II): 
sensitivity studies, Atmos. Chem. Phys., 6, 5261-5277, 2006, http://www.atmos-chem-phys.net/6/5261/2006/.

Mazzoni, D., Logan, J. A., Diner, D., Kahn, R., Tong, L., and Li, Q.: A data-mining approach to associating MISR smoke plume heights with MODIS fire measurements, Remote Sens. Environ., 107, 138-148, 2007.

Miller, S. M., Matross, D. M., Andrews, A. E., Millet, D. B., Longo, M., Gottlieb, E. W., Hirsch, A. I., Gerbig, C., Lin, J. C., Daube, B. C., Hudman, R. C., Dias, P. L. S., Chow, V. Y., and Wofsy, S. C.: Sources of carbon monoxide and formaldehyde in North America determined from high-resolution atmospheric data, Atmos. Chem. Phys., 8, 7673-7696, 2008,

http://www.atmos-chem-phys.net/8/7673/2008/.

Mims, S. R., Kahn, R. A., Moroney, C. M., Gaitley, B. J., Nelson, D. L., and Garay, M. J.: MISR stereo-heights of grassland fire smoke plumes in Australia, IEEE Trans. Geosci. Remote Sens., 48, 25-35, doi:10.1109/TGRS.2009.2027114, 2010.

Moroney, C., Davies, R., and Muller, J.-P.: Operational retrieval of cloud-top heights using MISR data, IEEE Trans. Geosci. Remote Sens., 40, 1541-1546, 2002.

Muller, J., Mandanayake, A., Moroney, C., Davies, R., Diner, D. J., and Paradise, S.: MISR stereoscopic image matchers: Techniques and results, IEEE Trans. Geosci. Remote Sens., 40, 15471559, 2002.

Nelson, D., Averill, C., Boland, S., Morford, R., Garay, M., Thompson, C., Hall, J., Diner, D., and Camphell, H.: MISR Interactive eXplorer (MINX) v1.0 User's Guide, Jet Propulsion Lab, NASA. Published on the web, https://www.openchannelsoftware.com/ projects/MINX, 2008a.

Nelson, D., Lawshe, C., Mazzoni, D., Diner, D., and Kahn, R.: MISR Plume Height Climatology Project: Quality Statement and Error and Bias Analysis, Jet Propulsion Lab, NASA. Published on the web, http://www-misr2.jpl.nasa.gov/EPA-Plumes/ suggestions4UsingData.cfm, 2008b.

Nelson, D., Lawshe, C., Mazzoni, D., Diner, D., and Kahn, R.: MISR Plume Height Climatology Project: Suggestion for using the data, Jet Propulsion Lab, NASA. Published on the web, http://www-misr2.jpl.nasa.gov/EPA-Plumes/ qualityStatement.cfm, 2008c.

Nelson, D. L., Chen, Y., Diner, D., Kahn, R. A., and Mazzoni, D.: Example applications of the MISR INteractive eXplorer (MINX) software tool to wildfire smoke plume applications, Proc. SPIE, 7089, 2008d.

Pfister, G. G., Emmons, L. K., Hess, P. G., Honrath, R., Lamarque, J.-F., Martin, M. V., Owen, R. C., Avery, M. A., Browell, E. V., Holloway, J. S., Nedelec, P., Purvis, R., Ryerson, T. B., Sachse, G. W., and Schlager, H.: Ozone production from the 2004 North American boreal fires, J. Geophys. Res., 111, D24S07, doi:10.1029/2006JD007695, 2006.

Pielke, R. A., Cotton, W. R., Walko, R. L., Tremback, C. J., Lyons, W. A., Grasso, L. D., Nicholls, M. E., Moran, M. D., Wesley, D. A., Lee, T. J., and Copeland, J. H.: A comprehensive meteorological modeling system - RAMS, Meteorol. Atmos. Phys, 49, 69-91, 1992.

Pu, R., Li, Z., Gong, P., Csiszar, I., Fraser, R., Hao, W.-M., Kondragunt, S., and Weng, F.: Development and analysis of a 12year daily $1-\mathrm{km}$ forest fire dataset across North America from NOAA/AVHRR, Remote Sens. Environ., 108, 198-208, 2007.

Real, E., Law, K. S., Weinzierl, B., Fiebig, M., Petzold, A., Wild,
O., Methven, J., Arnold, S., Stohl, A., Huntrieser, H., Roiger, A., Schlager, H., Stewart, D., Avery, M., Sachse, G., Browell, E., Ferrare, R., and Blake, D.: Processes influencing ozone levels in Alaskan forest fire plumes during long-range transport over the North Atlantic, J. Geophys. Res., 112, D10S41, doi:10.1029/2006JD007576, 2007.

Rienecker, M., Suarez, M., Todling, R., Bacmeister, J., Takacs, L., Liu, H.-C., Gu, W., Sienkiewicz, M., Koster, R., Gelaro, R., Stajner, I., , and Nielsen, J.: Technical Report Series on Global Modeling and Data Assimilation: The GEOS-5 Data Assimilation System Documentation of Versions 5.0.1, 5.1.0, and 5.2.0, Tech. Rep. NASA/TM2008104606, Vol. 27, 2008.

Sanchez-Ccoyllo, O. R., Dias, P. L. S., Andrade, M., and Freitas, S. R.: Determination of $\mathrm{O}_{3}, \mathrm{CO}$, and PM10 transport in the metropolitan area of Sao Paulo, Brazil through synoptic-scale analysis of back trajectories, Meteorol. Atmos. Phys., 92, 83-93, 2006.

Spracklen, D. V., Mickley, L. J., Logan., J. A., Hudman, R. C., Yevich, R., Flannigan, M. D., and Westerling, A. L.: Impacts of climate change from 2000 to 2050 on wildfire activity and carbonaceous aerosol concentrations in the western United States, J. Geophys. Res., 114, D2030, doi:10.1029/2008JD010966, 2009.

Stocks, B. J., Fosberg, M. A., Lynham, T. J., Mearns, L., Wotton, B. M., Yang, Q., Jin, J.-Z., Lawrence, K., Hartley, G. R., Mason, J. A., and McKenney, D. W.: Climate change and forest fire potential in Russian and Canadian boreal forests, Clim. Change, 38, 1-13, 1998.

Stocks, B. J., Mason, J. A., Todd, J. B., Bosch, E. M., Wotton, B. M., Amiro, B. D., Flannigan, M. D., Hirsch, K. G., Logan, K. A., Martell, D. L., and Skinner, W. R.: Large forest fires in Canada, 1959-1997, J. Geophys. Res., 108, 108(D1), 8149, doi: 10.1029/2001JD000484, 2003.

Stull, R. B.: An introduction to boundary layer meteorology, Kluwer Academic Publishers, Dordretcht, The Netherlands, 1988.

The Wilderness Society: 2002 wildfire season at a glance: Historic drought, historic fires, Tech. Rep. vol. 1, 2003.

Trentmann, J., Andreae, M. O., Graf, H.-F., Hobbs, P. V., Ottmar, R. D., and Trautmann, T.: Simulation of a biomass-burning plume: Comparison of model results with observations, J. Geophys. Res., 107, D24013, doi:10.1029/2001JD000410, 2002.

Trentmann, J., Luderer, G., Winterrath, T., Fromm, M. D., Servranckx, R., Textor, C., Herzog, M., Graf, H.-F., and Andreae, M. O.: Modeling of biomass smoke injection into the lower stratosphere by a large forest fire (Part I): reference simulation, Atmos. Chem. Phys., 6, 5247-5260, 2006, http://www.atmos-chem-phys.net/6/5247/2006/.

Turquety, S., Logan, J. A., Jacob, D. J., Hudman, R. C., Leung, F. Y., Heald, C. L., Yantosca, R. M., Wu, S., Emmons, L. K., Edwards, D. P., and Sachse, G. W.: Inventory of boreal fire emissions for North America in 2004: Importance of peat burning and pyroconvective injection, J. Geophys. Res., 112, D12S03, doi:10.1029/2006JD007281, 2007.

Val Martin, M., Honrath, R., Owen, R. C., Pfister, G., Fialho, P., and Barata, F.: Significant enhancements of nitrogen oxides, ozone and aerosol black carbon in the North Atlantic lower free troposphere resulting from North American boreal wildfires, J. Geophys. Res., 111, D23S60, doi:10.1029/2006JD007530, 2006.

Van Wagner, C. E.: Development and structure of the Canadian 
forest fire, Weather index system, Tech. Rep. Canadian Forest Service, Forestry Technical Report 35, 37 p., 1987.

Wofsy, S. C., Sachse, G. W., Gregory, G. L., Blake, D. R., Bradshaw, J. D., Sandholm, S. T., Singh, H. B., Barrick, J. A., Harriss, R. C. R. C., Talbot, R. W., Shipham, M. A., Browell, E. V., Jacob, D. J., and Logan, J. A.: Atmospheric chemistry in the Arctic and subarctic: Influence of natural fires, industrial emissions, and stratospheric inputs, J. Geophys. Res., 97, 16,731-16,746, 1992.
Wotawa, G. and Trainer, M.: The influence of Canadian forest fires on pollutant concentrations in the United States, Science, 288(5464), 324-328, 2000.

Zhang, X. and Kondragunta, S.: Temporal and spatial variability in biomass burned areas across the USA derived from the GOES fire product, Remote Sens. Environ., 112, 2886-2897, 2008. 